COVER: Lower Tenmile Creek near mouth, near Helena, Montana, looking downstream. Photograph by Patricia S. Hettinger, Lewis and Clark County. 
U.S. Department of the Interior

U.S. Geological Survey

Streamflow and Water Quality of the Lower

Tenmile Creek Watershed, Lewis and Clark County, West-Central Montana, 1997 and 1998

By Charles Parrett and Eloise Kendy

Water-Resources Investigations Report 01-4120

In cooperation with

LEWIS AND CLARK COUNTY and the

MONTANA DEPARTMENT OF NATURAL

RESOURCES AND CONSERVATION

Helena, Montana

August 2001 


\section{U.S. Department of the Interior}

GALE A. NORTON, Secretary

\section{U.S. Geological Survey}

Charles G. Groat, Director

Any use of trade, product, or firm name in this publication is for descriptive purposes only and does not imply endorsement by the U.S. Government

For additional information write to:

District Chief

U.S. Geological Survey

3162 Bozeman Avenue

Helena, MT 59601-6456

Copies of this report may be purchased from:

\section{U.S. Geological Survey}

Branch of Information Services

Box 25286

Denver, CO 80225-0286 


\section{CONTENTS}

Abstract

Introduction

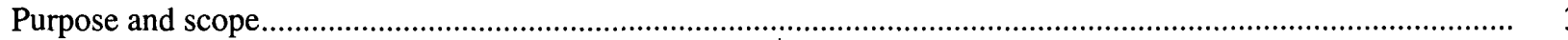

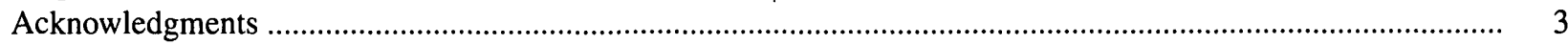

Streamflow

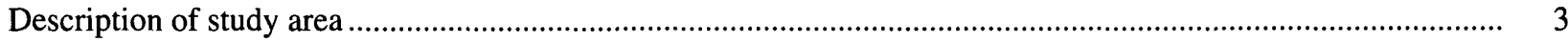

Data-collection methods

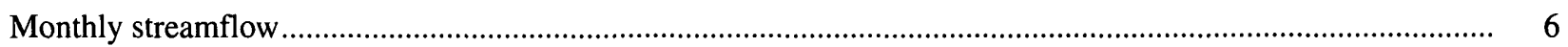

Synoptic streamflow measurements .......................................................................................................... 9

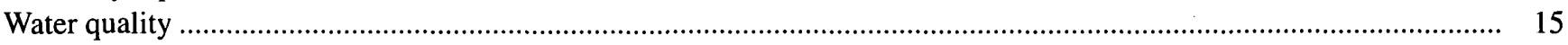

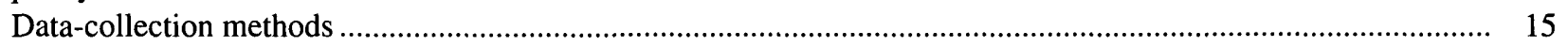

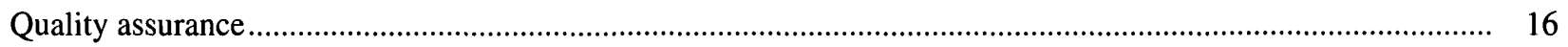

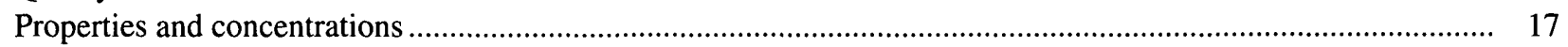

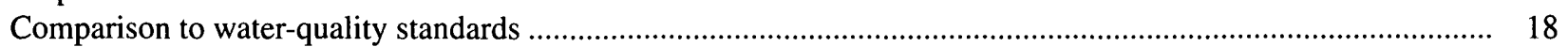

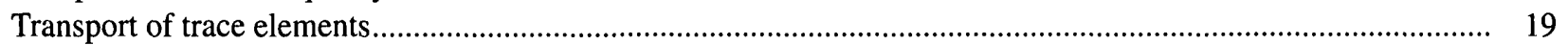

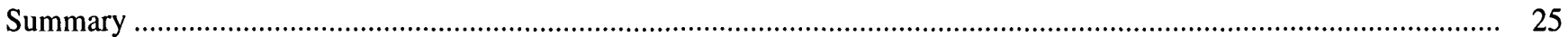

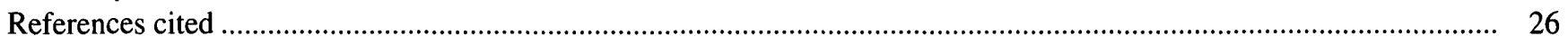

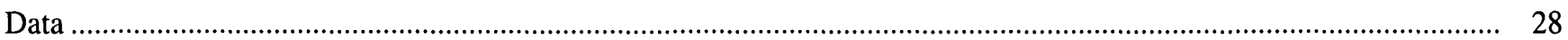

\section{ILLUSTRATIONS}

Figure 1. Map showing location of the Tenmile Creek watershed, predominant land use, inactive mines, and long-term streamflow-gaging stations, Lewis and Clark County, Montana ........................... 2

2. Map showing streamflow and water-quality sites in the lower Tenmile Creek study area, Montana............ 4

Figure 3-7. Graphs showing:

3. Mean monthly streamflow for two sites on Tenmile Creek, Montana, 1914-54, 1997, and 1998 ...... 7

4. Monthly mean streamflow for five sites on Tenmile Creek, Montana, 1997 and $1998 \ldots \ldots \ldots \ldots \ldots \ldots \ldots \ldots . . . . . \quad 9$

5. Comparison of monthly mean streamflow in 1997 and 1998 to long-term mean monthly streamflow at two sites on Tenmile Creek, Montana.

6. Comparison of recorded streamflow to synoptic streamflow measurements at selected sites, lower Tenmile Creek, Montana ......

7. Synoptic streamflow measurements and adjusted streamflow at selected sites on lower Tenmile Creek, Montana, 1997 and 1998.

Figure 8-11. Graphs showing concentration at selected mainstem sites and Sevenmile Creek, a tributary, in the lower Tenmile Creek watershed, Montana, 1997:

8. Total-recoverable arsenic concentration compared to the State of Montana human-health standard for drinking water.

9. Total-recoverable cadmium concentration compared to State of Montana aquatic-life standards for acute and chronic toxicity ..

10. Total-recoverable copper concentration compared to State of Montana aquatic-life standards for acute and chronic toxicity .

9

11. Total-recoverable lead concentration compared to State of Montana aquatic-life standards for chronic toxicity.

Figure 12-16. Graphs showing instantaneous loads at selected mainstem sites and Sevenmile Creek, a tributary, in the lower Tenmile Creek watershed, Montana, 1997:

12. Arsenic

13. Cadmium

14. Copper.

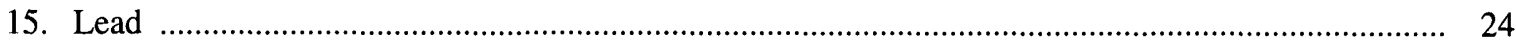

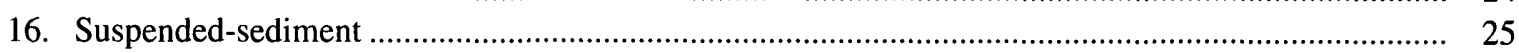




\section{TABLES}

Table 1. Streamflow and water-quality sites and types of data collected in the lower Tenmile Creek watershed, Montana .

2. Monthly mean streamflow for five sites on Tenmile Creek, Montana, 1997 and 1998

3. Synoptic streamflow measurements at sites in the lower Tenmile Creek watershed, Montana, 1997 and 1998

4. Analytical methods, minimum reporting levels, and water-quality standards for constituents analyzed in water samples from the lower Tenmile Creek watershed, Montana

5. Field-measured parameters and concentrations of major ions and nutrients in the lower Tenmile Creek watershed, Montana, 1997

6. Concentrations of trace elements and suspended sediment in streams in the lower Tenmile Creek

7. Equations for calculation of State of Montana freshwater aquatic-life standards based on ambient hardness

8. Instantaneous trace-element and suspended-sediment loads in the lower Tenmile Creek watershed, Montana, 1997

\section{CONVERSION FACTORS, VERTICAL DATUM, ABBREVIATED UNITS, AND ACRONYMS}

\begin{tabular}{rll}
\hline Multiply & By & To obtain \\
acre & 0.407 & hectare \\
acre-foot (acre-ft) & 1,233 & cubic meter \\
cubic foot per second & 0.028317 & cubic meter per second \\
foot (ft) & 0.3048 & meter (m) \\
inch (in.) & 25.4 & millimeter (mm) \\
mile (mi) & 1.609 & kilometer \\
pounds per day & 453.6 & grams per day \\
square mile (mi $\left.{ }^{2}\right)$ & 2.59 & square kilometers \\
\hline
\end{tabular}

Temperature can be converted to degrees Celsius $\left({ }^{\circ} \mathrm{C}\right)$ or degrees Fahrenheit $\left({ }^{\circ} \mathrm{F}\right)$ by the following equations:

$$
\begin{aligned}
& { }^{\circ} \mathrm{C}=5 / 9\left({ }^{\circ} \mathrm{F}-32\right) \\
& { }^{\circ} \mathrm{F}=9 / 5\left({ }^{\circ} \mathrm{C}\right)+32
\end{aligned}
$$

Sea level: In this report, "sea level" refers to the National Geodetic Vertical Datum of 1929 (NGVD of 1929)--a geodetic datum derived from a general adjustment of the first-order level nets of both the United States and Canada, formerly called Sea Level Datum of 1929.
Abbreviated units used in this report:
Acronyms used in this report:
$\mathrm{mg} / \mathrm{L} \quad$ milligram per liter
NWQL National Water Quality Laboratory
$\mathrm{mm} \quad$ millimeter
TIGER/Line Topologically Integrated Geographically Encoding and Referencing System
$\mu \mathrm{g} / \mathrm{L} \quad$ microgram per liter
USGS U.S. Geological Survey
$\mu \mathrm{S} / \mathrm{cm} \quad$ microsiemen per centimeter at 25 degrees Celsius
$\mu \mathrm{m} \quad$ micrometer (micron)

Water-year definition:

A water year is the 12-month period from October 1 through September 30 . It is designated by the calendar year in which it ends. 


\title{
Streamflow and Water Quality of the Lower Tenmile Creek Watershed, Lewis and Clark County, West-Central Montana, 1997 and 1998
}

\author{
By Charles Parrett and Eloise Kendy
}

\begin{abstract}
A reconnaissance investigation of streamflow and water quality in the lower Tenmile Creek watershed near Helena, Montana, was conducted by the U.S. Geological Survey, in cooperation with Lewis and Clark County and the Montana Department of Natural Resources and Conservation, in 1997 and 1998.

Streamflow data were collected at one year-round and three seasonal streamflow-gaging stations, and at two periodic measurement sites. Three sets of synoptic streamflow measurements were made at 21 sites.

Streamflow varies from site to site in the study area as a result of complex patterns of runoff, ground-water and surface-water interaction, and diversion management. Flow increases were attributed mostly to tributary inflow, and flow losses largely were attributed to irrigation diversions. Synoptic measurements verified the general pattern of flow gains and losses shown by the streamflow-gaging station records.
\end{abstract}

Water-quality samples for the analysis of major ions, nutrients, trace elements, and suspended sediment were obtained at the four streamflow-gaging stations and two additional sites three times in 1997; samples for analysis of herbicides were collected once at two sites. Water in lower Tenmile Creek was determined to be a calcium bicarbonate type, with generally low concentrations of major ions and nutrients. Totalrecoverable arsenic concentrations were near, and occasionally exceeded, the State of Montana humanhealth standard for drinking water. Cadmium, copper, lead, and zinc had concentrations in excess of the State of Montana aquatic-life standards for some samples and locations. Suspended-sediment concentrations generally were low. No detectable concentrations of herbicides were found.

\section{INTRODUCTION}

Tenmile Creek drains about $200 \mathrm{mi}^{2}$ of mountainous and valley terrain near the City of Helena, Mont. Lower Tenmile Creek, defined as the reach below the Tenmile Water Treatment Plant (fig. 1), drains about 150 square miles and flows about 15 miles to its confluence with Prickly Pear Creek just upstream from Lake Helena. Water and land uses affect both streamflow and water quality of lower Tenmile Creek.

Water from upper Tenmile Creek (upstream from the Tenmile Water Treatment Plant) is primarily used for municipal-water supply for Helena, and water from lower Tenmile Creek is used mostly for irrigation for parts of the Helena Valley. Diversions for municipalwater supply in the upper Tenmile Creek watershed and for irrigation in the lower watershed deplete streamflow in lower Tenmile Creek during summer months, causing some reaches to go dry in most years. Watermanagement programs, such as water-rights leasing, recently have been initiated in Montana and might provide a way to help maintain perennial instream flows. However, the timing and degree of water management needed to achieve this goal are not known because of limited available streamflow data.

Land use in the lower Tenmile Creek watershed is dominated by forest, irrigated hay and small-grain production (cropland), livestock grazing (rangeland), and residential and commercial development (urban/ suburban) (fig. 1). The mountainous headwater areas in the upper Tenmile Creek watershed are mostly forested and have a history of hard-rock mining dating to the late $1800 \mathrm{~s}$. Inactive mine sites, which may have impacted aquatic resources or are considered to be a potential source of trace elements to streams in the watershed, are shown in figure 1 . The effects of landuse and water-use practices on water quality are a major concern to water-resource managers; however, water quality had not been systematically analyzed and 


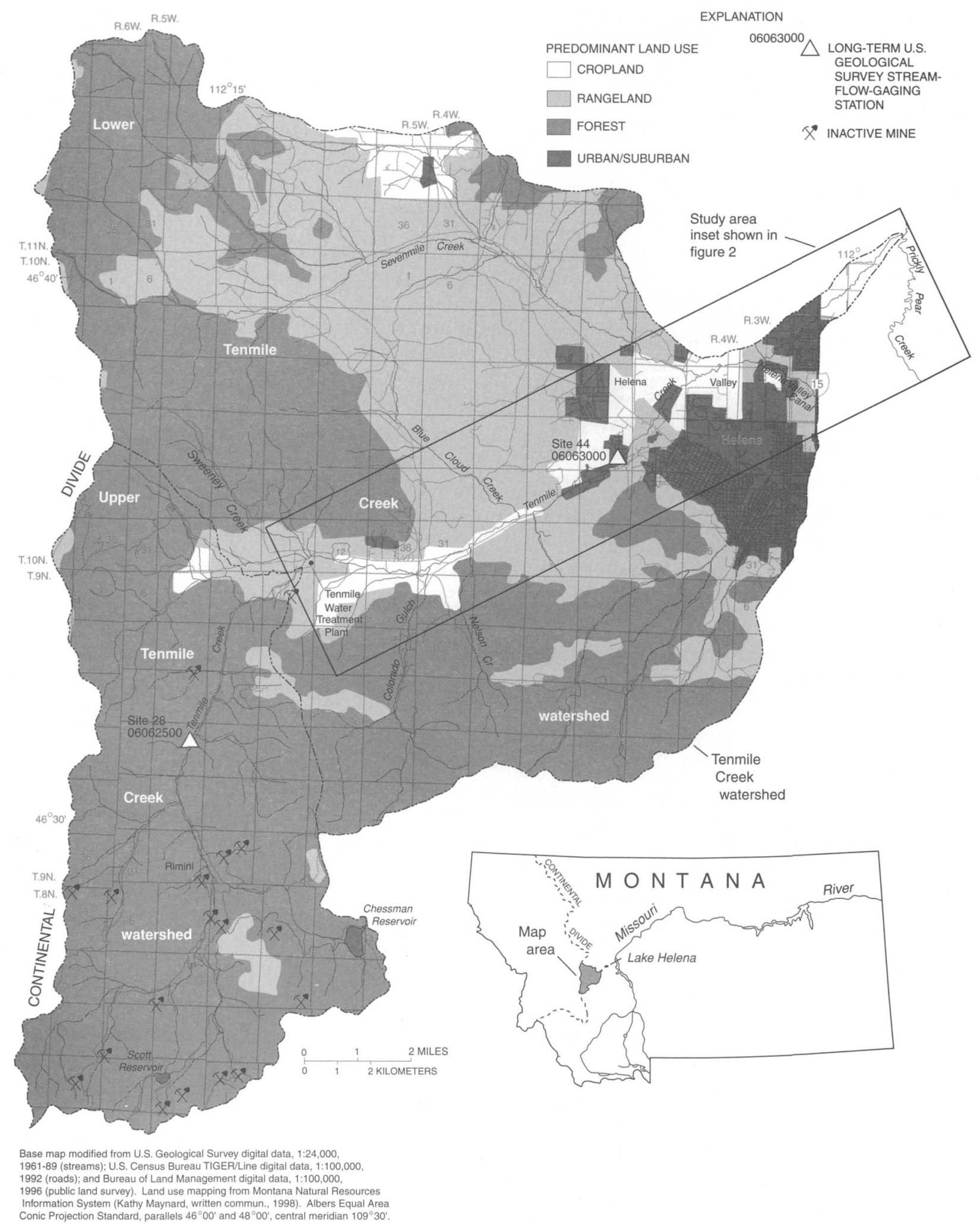

Figure 1. Location of the Tenmile Creek watershed, predominant land use, inactive mines, and long-term streamflow-gaging stations, Lewis and Clark County, Montana. 
documented in the basin. Data characterizing streamflow and water quality in the lower Tenmile Creek basin were needed as a benchmark for evaluating effectiveness of water-management efforts and various upstream reclamation activities.

In response to the need for streamflow and waterquality information, the U.S. Geological Survey (USGS), in cooperation with Lewis and Clark County and Montana Department of Natural Resources and Conservation, conducted a reconnaissance investigation in 1997 and 1998. The results of the investigation can be used to help guide future management of the lower Tenmile Creek watershed.

\section{Purpose and Scope}

This report describes the streamflow and water quality of the lower Tenmile Creek watershed during 1997 and 1998. Streamflow data for the study period are described, compared to long-term records, and used to identify gaining and losing reaches of lower Tenmile Creek. Water-quality data for the study period are described, compared to environmental criteria, and used to estimate instantaneous mass loads of selected constituents.

Data-collection sites are listed in table 1 and shown in figure 2. For this report, site numbers begin with number 34 because data were collected concurrently for site numbers 1 through 33 in the upper Tenmile Creek watershed (Parrett and Hettinger, 2000).

All sites, except those having current or discontinued streamflow-gaging stations, also are assigned a fifteendigit USGS site-identification number (table 1). These numbers represent the approximate latitude and longitude of the site in degrees, minutes, and seconds (first 13 digits), plus the sequence number (last 2 digits). Sites having current or discontinued streamflowgaging stations are assigned standard USGS eight-digit station-identification numbers (table 1) that increase in a downstream direction according to geographic location within a drainage basin.

Streamflow was continuously recorded on a year-round basis from May 1, 1997 through September 30,1998 at one streamflow-gaging station (06062750, site 34). Streamflow also was continuously recorded on a seasonal basis from May 1 through October 31, 1997 and from April 1 through September 30, 1998 at three streamflow-gaging stations (stations 06063000 , site 44;06064100, site 49; and 06064150, site 54).
Station 06063000 previously was operated on a yearround basis from 1909-54. Periodic measurements of streamflow were made at two other sites during times of water-quality sampling (sites 40 and 48 ). Synoptic streamflow measurements were made at 21 sites on August 13, 1997; September 10, 1997; and April 22, 1998 to determine gaining and losing reaches of the stream channel. The synoptic measurement sites included the streamflow-gaging stations and periodic measurement sites. Water-quality samples were collected at the four streamflow-gaging stations and two periodic measurement sites on June 4-5, August 27-28, and October 8-9, 1997, and analyzed for major ions, nutrients, trace elements, and suspended sediment. In addition, water-quality samples were collected at two sites on September 15, 1997, and analyzed for selected herbicides.

\section{Acknowledgments}

Patricia S. Hettinger, Lewis and Clark County Water Quality District, assisted with water-quality sampling and provided valuable technical guidance throughout the investigation. Appreciation is extended to Montana Tunnels, Inc. for analyzing water samples at their Water Quality Laboratory in Jefferson City, Mont., and for participating in the USGS laboratory certification program. Appreciation also is extended to the many landowners in the study area who allowed access to the streams on their land for measurement and sampling purposes.

\section{Description of Study Area}

The lower Tenmile Creek watershed is located primarily west and south of Helena. Streamflow in lower Tenmile Creek is partly controlled by two small, municipal-supply reservoirs (Scott and Chessman) in the upper watershed (fig. 1) and by diversions for municipal water supply and irrigation. Annual diversions for municipal supply ranged from 1,560 to 6,280 acre-ft during 1978 to 1997 , and the average annual diversion for this period was 3,910 acre-ft (Leonard Willett, City of Helena, written commun., 1998). The diverted water is piped from five headwater stream diversions to the Tenmile Water Treatment Plant. The water diverted from upper Tenmile Creek provides about 70 percent of the municipal supply for Helena from June through September and 100 percent of the city supply from October through May (Hettinger, 

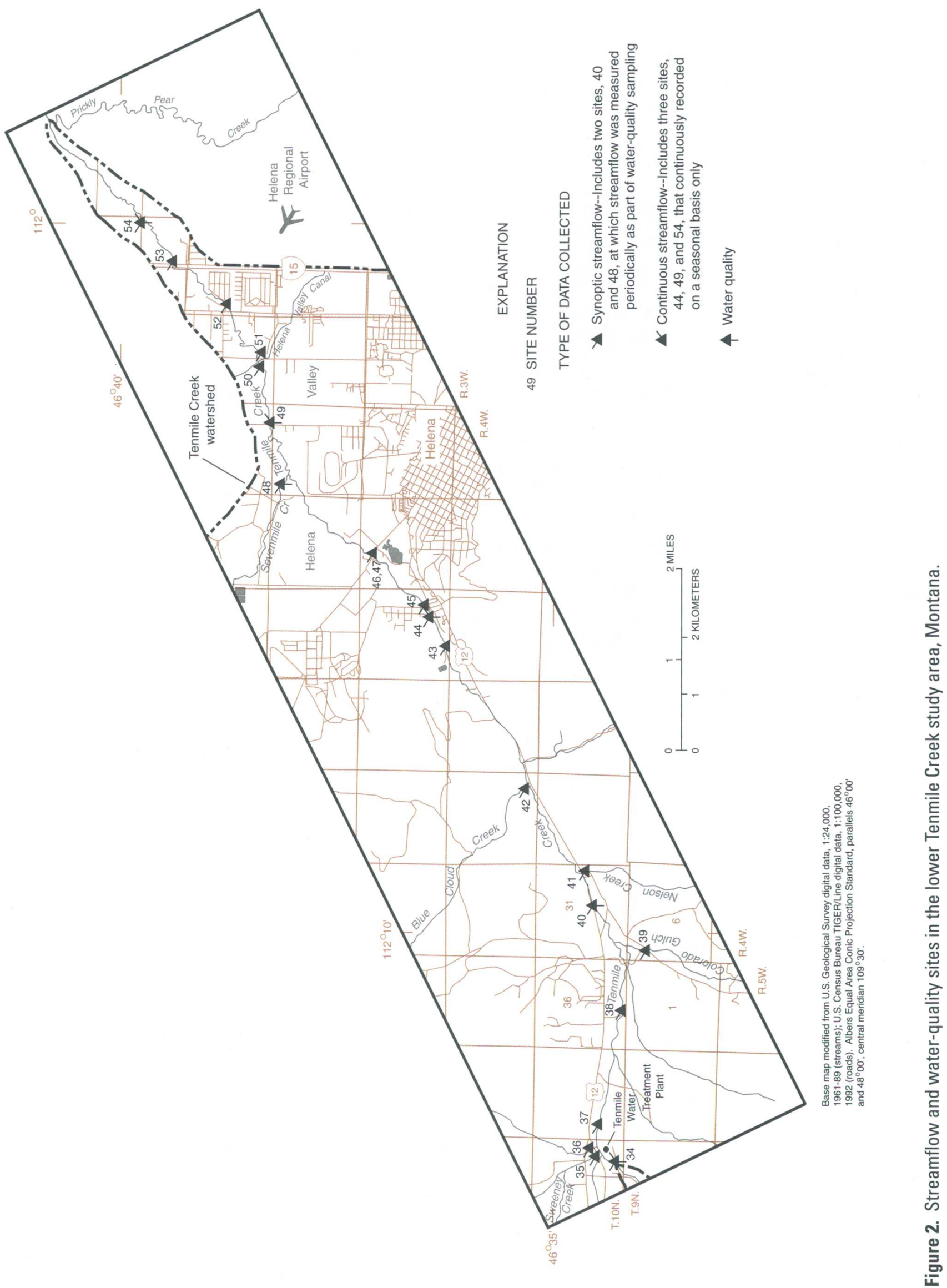
Table 1. Streamflow and water-quality sites and types of data collected in the lower Tenmile Creek watershed, Montana

[Data type: $\mathrm{C}$, continuous-record streamflow; $\mathrm{H}$, water-quality analyses for herbicides; $\mathrm{P}$, periodic-streamflow measurement; S, synopticstreamflow measurement; $\mathrm{W}$, water-quality analyses for major ions, nutrients, trace elements, and suspended sediment. Abbreviation: $\mathrm{mi}^{2}$, square miles. Symbol: --, no data]

\begin{tabular}{|c|c|c|c|c|}
\hline $\begin{array}{c}\text { Site } \\
\text { number } \\
\text { (fig. 2) }\end{array}$ & $\begin{array}{c}\text { Drainage } \\
\text { area } \\
\left(\mathrm{mi}^{2}\right)\end{array}$ & $\begin{array}{l}\text { U.S. Geological } \\
\text { Survey } \\
\text { site-identification } \\
\text { number }^{1}\end{array}$ & Station name & Data type \\
\hline 34 & 51.1 & $06062750^{2}$ & Tenmile Creek at Tenmile Water Treatment Plant, near Rimini & $\mathrm{C}, \mathrm{S}, \mathrm{W}$ \\
\hline 35 & 6.79 & 463430112124501 & Sweeney Creek at Highway 12, near Helena & $\mathrm{S}$ \\
\hline 36 & .52 & 463430112124401 & Unnamed tributary at Highway 12 , east of Sweeney Creek, near Helena & $\mathrm{S}$ \\
\hline 37 & 58.6 & 463431112122301 & Tenmile Creek below Sweeney Creek, near Helena & $\mathrm{S}$ \\
\hline 38 & 64.3 & 463420112104501 & Tenmile Creek at Ballou's bridge, near Helena & S \\
\hline 39 & 10.1 & 463405112095201 & Colorado Gulch at Colorado Gulch Road, at Highway 12, near Helena & $\mathrm{S}$ \\
\hline 40 & 77.8 & 463438112091801 & Tenmile Creek below Colorado Gulch, near Helena & $\mathrm{P}, \mathrm{S}, \mathrm{W}$ \\
\hline 41 & 5.23 & 463445112084901 & Nelson Creek at Highway 12, near Helena & $S$ \\
\hline 42 & 7.37 & 463519112074101 & Blue Cloud Creek near Helena & S \\
\hline 43 & 96.2 & $06062990^{3}$ & Tenmile Creek at State Nursery bridge, near Helena & $\mathrm{S}$ \\
\hline 44 & 96.5 & $06063000^{4}$ & Tenmile Creek near Helena & $\mathrm{C}, \mathrm{S}, \mathrm{W}$ \\
\hline 45 & -- & 463619112051101 & Unnamed ditch below Williams Street bridge, near Helena & $S$ \\
\hline 46 & 97.3 & 463653112043601 & Tenmile Creek at Country Club Avenue, near Helena & $\mathrm{S}$ \\
\hline 47 & -- & 463653112043602 & Return flow ditch at Country Club Avenue, near Helena & $\mathrm{S}$ \\
\hline 48 & 57.2 & 463747112033801 & Sevenmile Creek at mouth, near Helena & $\mathrm{P}, \mathrm{S}, \mathrm{W}$ \\
\hline 49 & 161 & $06064100^{5}$ & Tenmile Creek at Green Meadow Drive, at Helena & $\mathrm{C}, \mathrm{H}, \mathrm{S}, \mathrm{W}$ \\
\hline 50 & 165 & 463803112015201 & Tenmile Creek at McHugh Lane, near Helena & $\mathrm{S}$ \\
\hline 51 & -- & 463803112015301 & Helena Valley Canal Siphon at McHugh Lane, near Helena & $\mathrm{S}$ \\
\hline 52 & 180 & 463823112010601 & Tenmile Creek at Valley Forge Road, near Helena & $S$ \\
\hline 53 & 188 & 463854112003601 & Tenmile Creek at Interstate Highway 15, near Helena & $\mathrm{S}$ \\
\hline 54 & 188 & $06064150^{5}$ & Tenmile Creek above Prickly Pear Creek, near Helena & $\mathrm{C}, \mathrm{H}, \mathrm{S}, \mathrm{W}$ \\
\hline
\end{tabular}

'Fifteen-digit site-identification number is a unique identifier that represents the approximate latitude and longitude location of the site in degrees, minutes, and seconds (first 13 digits), plus the sequence number (last two digits). Eight-digit station identification number represents the standard USGS streamflow-gaging station numbering system wherein numbers increase in a downstream direction according to geographic location within the drainage basin.

${ }^{2}$ Streamflow-gaging station operated year-round from May 1997 through September 1998.

${ }^{3}$ Discontinued streamflow-gaging station operated seasonally during 1992-93.

${ }^{4}$ Streamflow-gaging station operated year-round from 1909-54 and seasonally during 1997 and 1998.

${ }^{5}$ Streamflow-gaging station operated seasonally during 1997 and 1998. 
1996). Parrett and Hettinger (2000) provided a detailed description of the diversions from upper Tenmile Creek and estimated the long-term natural streamflow in upper Tenmile Creek.

Water from lower Tenmile Creek was first diverted for irrigation when land grants were claimed in the late 1800s. Currently, water (when available) is diverted from lower Tenmile Creek and used to irrigate about 4,700 acres. Some water also is diverted from lower Tenmile Creek for livestock watering (J.P. Gilman, Montana Department of Natural Resources and Conservation, oral commun., 1997).

Streamflow in the 3-mi reach of lower Tenmile Creek between site 50 and the confluence with Prickly Pear Creek (fig. 2) is supplemented at times with water from the Helena Valley Irrigation District. The Helena Valley Irrigation District manages the annual diversion of about 63,000 acre-ft of water from the Missouri River to the Helena Valley Regulating Reservoir, which discharges into the Helena Valley Canal. This canal nearly encircles the Helena Valley alluvial plain, and water is distributed to the central part of the Helena Valley through an extensive network of lateral canals. This irrigation water can discharge to lower Tenmile Creek in the form of direct spills or irrigation return flow from either surface-water or ground-water sources.

Vegetation in the lower Tenmile Creek watershed is typical of most valleys in western Montana, where the species composition has been heavily influenced by agriculture. The dominant crops are alfalfa and various grasses cultivated for pasture or hay. The riparian corridors along lower Tenmile Creek that are not cultivated or grazed are dominated by willows, particularly sandbar willow. Water birch also is present. Small stands of cottonwood trees can be found in some of the riparian areas along the lower reaches of lower Tenmile Creek (Kendy and others, 1998).

The lower Tenmile Creek watershed has a continental climate characterized by cold winters, mild summers, and little precipitation. The Helena Regional Airport weather station is located $1 \mathrm{mi}$ east of the study area at an altitude of 3,831 ft. On the basis of the 1961-90 period of record, the average annual temperature at the Helena Regional Airport is $44.0^{\circ} \mathrm{F}$ and the average annual precipitation is 11.6 in. (National Oceanic and Atmospheric Administration, 1992). The average frost-free period is from May 18 to September 20 (Natural Resources Conservation Service, U.S.
Department of Agriculture, unpub. data, 1994).

Because evapotranspiration generally exceeds precipitation, irrigation is required to sustain most crops through the summer growing season.

\section{STREAMFLOW}

\section{Data-Collection Methods}

Streamflow-gaging stations were installed and operated at four sites in accordance with procedures described by Rantz and others (1982). Stage-discharge relationships were based on measured stage and discharge under a wide range of hydrologic conditions. Discharge at the four gaging stations within the lower watershed, a long-term gaging station in the upper watershed, and the periodic and synoptic measurement sites was measured using standard USGS methods described by Rantz and others (1982) and White and others (1998).

\section{Monthly Streamflow}

Long-term streamflow data for Tenmile Creek are available at one USGS streamflow-gaging station in the upper watershed (06062500, site 28) and one USGS streamflow-gaging station in the lower Tenmile Creek watershed (06063000, site 44) (fig. 1). Concurrent streamflow records for these two sites are available for the period 1914-54; May-October, 1997; and AprilSeptember, 1998. Differences in recorded concurrent streamflow at the two sites include the effects of tributary inflows and diversions for municipal water supply and irrigation over the period of record. Based on the period of concurrent record, hydrographs in figure 3 indicate that mean monthly streamflow of lower Tenmile Creek is slightly greater than upper Tenmile Creek and that the seasonal pattern of streamflow is similar for both sites. The largest differences in monthly flows between the two sites are in May and June when tributary inflow is likely at a maximum. The seasonal pattern is typical of mountain streams in Montana, with the largest mean monthly flows occurring in May and June as a result of snowmelt and rainfall runoff, and the smallest mean monthly flows occurring from late summer through winter, when almost all flow is from ground-water discharge to the stream.

Despite the similarity of monthly flows at the two sites, the drainage area of the lower site $\left(96.5 \mathrm{mi}^{2}\right)$ 


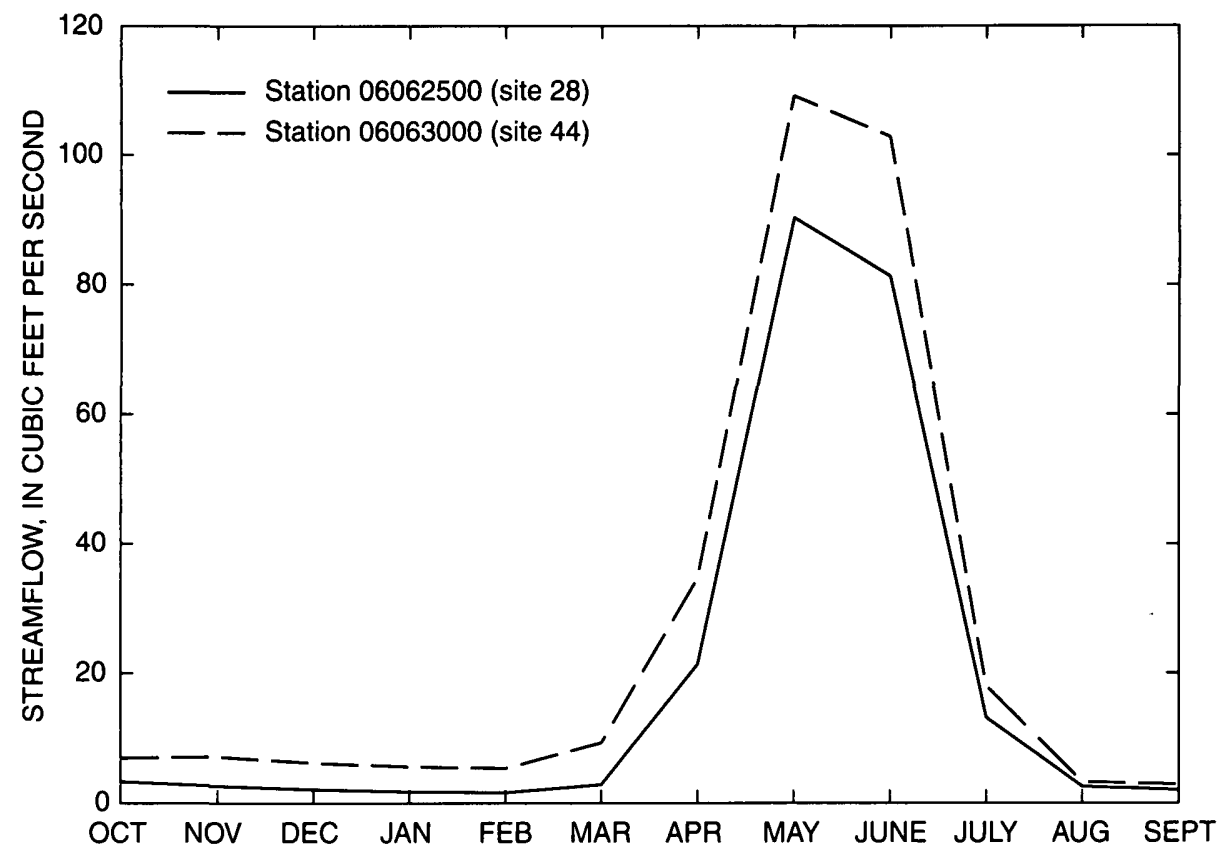

Figure 3. Mean monthly streamflow for two sites on Tenmile Creek, Montana, 1914-54, 1997, and 1998.

is more than three times that of the upper site (31.9 $\mathrm{mi}^{2}$ ). Thus, for most months, either little additional streamflow is contributed to Tenmile Creek from the intervening drainage area between sites 28 and 44 or diversions are sufficiently large to offset flow increases caused by tributary inflows.

Although long-term mean monthly streamflow is greater at site 44 than at site 28 for all months, monthly streamflow in a given year may vary from site to site in the lower Tenmile Creek watershed, particularly during the irrigation season. Variations in streamflow are not always consistent from month to month and reflect complex patterns of runoff, ground-water and surfacewater interaction, and diversion management. Monthly mean streamflow data for 1997 and 1998 for five sites in the upper and lower watersheds are presented in table 2 and in figure 4. As shown in figure 4, monthly mean streamflows typically, although not always, increased from site 28 to site 34 . From site 34 to site 44 , monthly mean streamflow increased some months, decreased some months, and remained about the same some months. Tributary inflows, most notably Colorado Gulch, probably account for streamflow increases in this reach. Streamflow decreases in this reach are most likely the result of an irrigation diversion located just upstream from site 44 . From site 44 to site 49 , monthly mean streamflow increased during most months, primarily because tributary inflow from Sevenmile Creek, together with ground-water inflows, were greater than irrigation diversions and groundwater outflows in the reach. Finally, streamflow decreased in the reach from site 49 to site 54 in every month. The decreases presumably are the result of irrigation diversions, together with seepage losses to ground water, that exceeded all intervening inflow from irrigation return flows or direct spills from the Helena Valley Canal.

To determine whether monthly mean streamflow characteristics (fig. 4) for the 1997 and 1998 period were typical of long-term mean monthly streamflow characteristics, mean flows for the periods 1914-54 and 1997 and 1998 at sites 28 and 44 were compared with monthly streamflows during the study period (fig. 5). Figure 5 indicates that streamflows in 1997 and 1998 generally were, on average, about the same as for the long-term period. In May 1997, streamflows at both stations were greater than the long-term means, whereas streamflows in May 1998 at both stations were less than the long-term means. Streamflows at site 28 during June of 1997 and 1998 were similar to the 


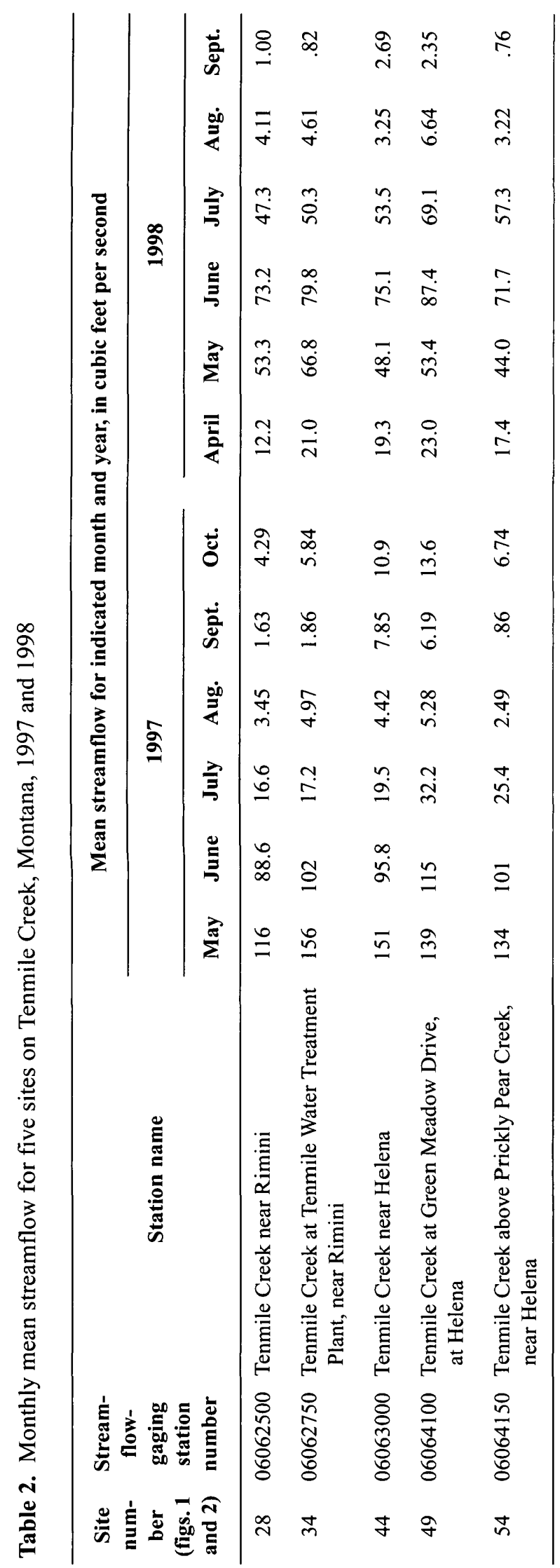




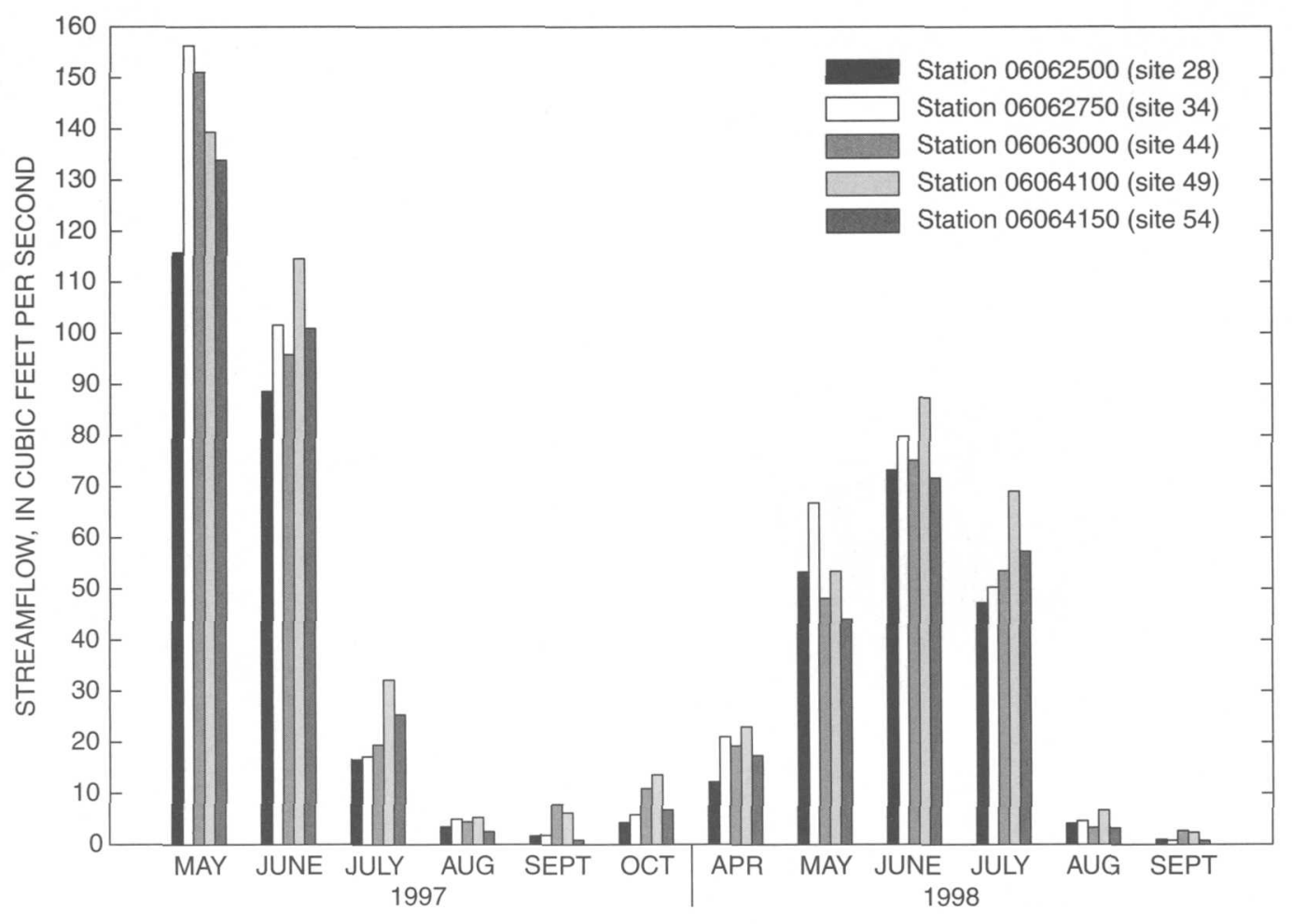

Figure 4. Monthly mean streamflow for five sites on Tenmile Creek, Montana, 1997 and 1998.

long-term mean; however, June streamflows were smaller than the long-term mean during both years at site 44. Streamflows at both sites were nearly identical to the long-term means in July 1997, but streamflows at both stations were greater than the long-term means in July 1998. Overall, streamflows during the study period are considered to be reasonably representative of flows over the long term.

\section{Synoptic Streamflow Measurements}

Synoptic measurements are made over a broad area within a short period of time in an attempt to represent near-instantaneous conditions. Three sets of synoptic streamflow measurements were made at 21 sites in the lower watershed (fig. 2) to determine the location and magnitude of specific gains and losses in streamflow under different flow conditions during the irrigation season. Sites for synoptic streamflow measurement were selected on the mainstem above and below tributaries and diversions, on some tributaries and diversions, and where gains in streamflow from ground-water discharge or losses in streamflow due to seepage were expected. Synoptic-measurement sites also were carefully selected to ensure that streamflow could be accurately measured. Some measurement sites were located farther from tributaries or diversions than was desired in order to find a suitable channel cross section that would ensure accurate measurements. In addition, synoptic measurements were made at streamflow-gaging stations and periodic streamflowmeasurement sites used for water-quality sampling. The results of the synoptic streamflow measurements are presented in table 3 . The error of each synoptic streamflow measurement was estimated qualitatively on the basis of site conditions to be about \pm 10 percent of the measured streamflow.

The use of synoptic streamflow measurements to determine gains or losses in streamflow in selected reaches of lower Tenmile Creek is complicated by the unsteady flow conditions that often occur throughout the study reach. Unsteady flow conditions occur when streamflow at a site changes over a relatively short period of time as a result of runoff from an upstream thunderstorm, changes in upstream diversions, or natural diurnal changes in evapotranspiration. Thus, a 


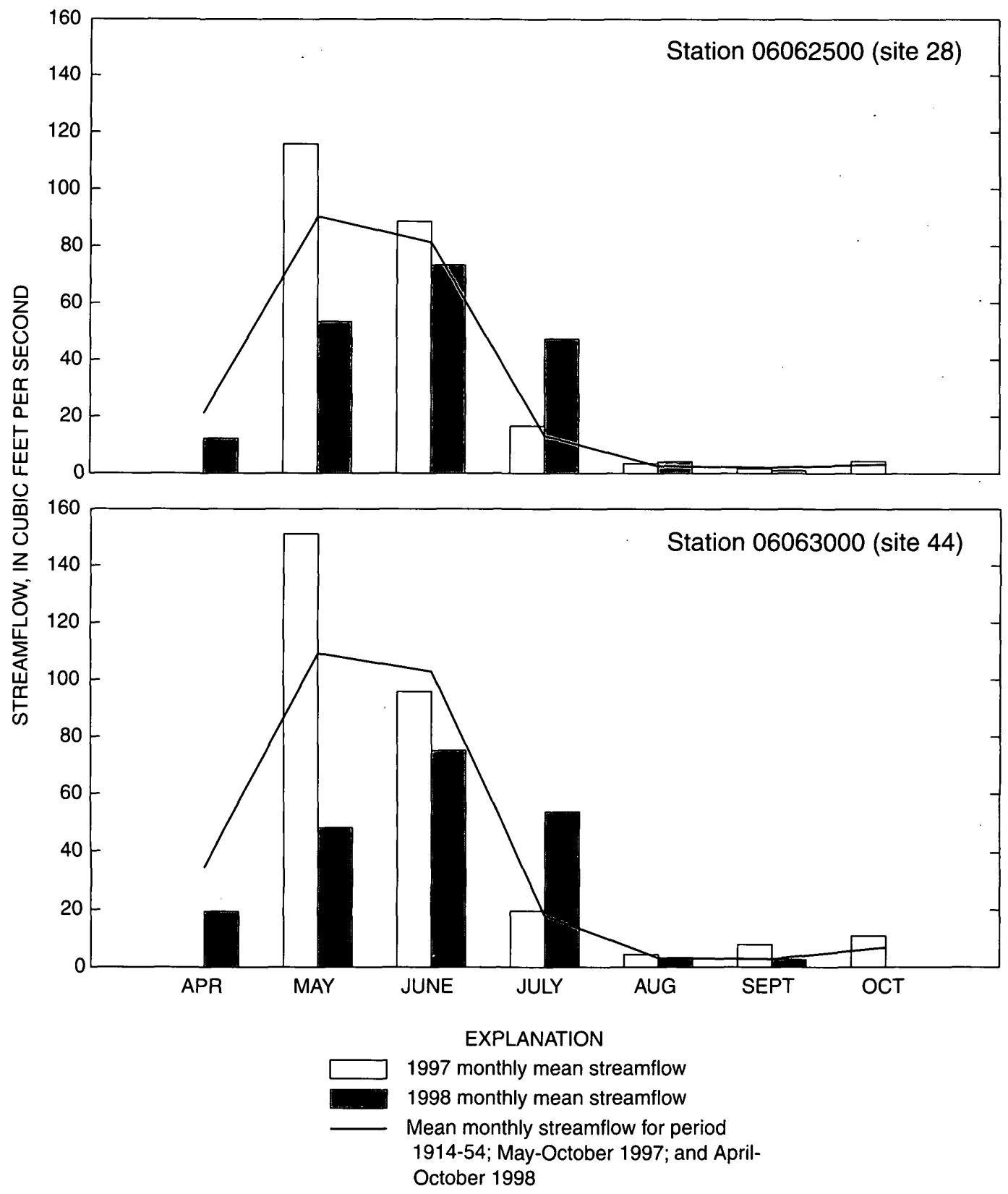

Figure 5. Comparison of monthly mean streamflow in 1997 and 1998 to long-term mean monthly streamflow at two sites on Tenmile Creek, Montana.

difference in measured streamflow from one site to another might be due to a lagged response to the unsteady flow conditions rather than a true gain or loss in streamflow from intervening tributary inflow, diversions, ground-water discharge, or seepage. Recorded streamflow data for three sites $(34,49,54)$ were used to determine if adjustments to measured streamflow were required to account for unsteady flow conditions at the times of synoptic streamflow measurements.

On August 13, 1997, streamflow at site 34, a gaging station at the upstream end of the study reach, had been decreasing slightly before the synoptic measurements, but was relatively steady for several hours before and after the synoptic measurements (fig. 6). The slightly decreasing trend in streamflow prior to 
Table 3. Synoptic streamflow measurements at sites in the lower Tenmile Creek watershed, Montana, 1997 and 1998 [Significant figures for streamflow vary based on accuracy of measurement and mathematical adjustments]

\begin{tabular}{|c|c|c|c|c|c|c|}
\hline \multirow[b]{2}{*}{$\begin{array}{l}\text { Site no. } \\
\text { (fig. 2) }\end{array}$} & \multirow[b]{2}{*}{$\begin{array}{c}\text { Distance } \\
\text { from } \\
\text { Tenmile } \\
\text { Water } \\
\text { Treatment } \\
\text { Plant } \\
\text { (miles) }\end{array}$} & \multirow[b]{2}{*}{ Station name } & \multicolumn{4}{|c|}{ Streamflow, in cubic feet per second } \\
\hline & & & $\begin{array}{c}\text { Aug. 13, } \\
1997\end{array}$ & $\begin{array}{c}\text { Sept. 10, } \\
1997\end{array}$ & $\begin{array}{c}\text { Sept. 10, } \\
1997 \\
\text { (adjusted } \\
\text { for } \\
\text { unsteady } \\
\text { flow }^{1} \text { ) }\end{array}$ & $\begin{array}{l}\text { Apr. 22, } \\
1998\end{array}$ \\
\hline 34 & 0.0 & Tenmile Creek at Tenmile Water Treatment Plant, near Rimini & 2.20 & 3.75 & 1.0 & 19.2 \\
\hline 35 & .30 & Sweeney Creek at Highway 12, near Helena & .15 & .09 & .09 & .95 \\
\hline 36 & .34 & Unnamed tributary at Highway 12 , east of Sweeney Creek, near Helena & 0 & 0 & 0 & 0 \\
\hline $37^{2}$ & .42 & Tenmile Creek below Sweeney Creek, near Helena & 3.00 & 4.27 & 1.6 & 19.8 \\
\hline 38 & 2.52 & Tenmile Creek at Ballou's bridge, near Helena & 5.61 & 5.67 & 3.5 & 20.5 \\
\hline $39^{3}$ & 2.81 & Colorado Gulch at Colorado Gulch Road, at Highway 12, near Helena & .98 & .88 & .88 & 3.87 \\
\hline 40 & 3.29 & Tenmile Creek below Colorado Gulch, near Helena & 9.39 & 7.21 & 5.2 & 24.7 \\
\hline 41 & 3.73 & Nelson Creek at Highway 12, near Helena & 0 & 0 & 0 & 0 \\
\hline 42 & 5.00 & Blue Cloud Creek near Helena & 0 & 0 & 0 & 0 \\
\hline 43 & 7.16 & Tenmile Creek at State Nursery bridge, near Helena & 10.2 & 6.4 & 5.4 & 24.7 \\
\hline 44 & 7.68 & Tenmile Creek near Helena & .5 & 7.16 & 6.3 & 16.8 \\
\hline $45^{4}$ & 7.68 & Unnamed ditch below Williams Street bridge, near Helena & 0 & .44 & .44 & .3 \\
\hline 46 & 8.62 & Tenmile Creek at Country Club Avenue, near Helena & .01 & 5.00 & 4.4 & 13.3 \\
\hline $47^{5}$ & 8.62 & Return flow ditch at Country Club Avenue, near Helena & .1 & .05 & .05 & .1 \\
\hline $48^{6}$ & 10.17 & Sevenmile Creek at mouth, near Helena & 5.12 & 3.09 & 3.09 & 2.20 \\
\hline 49 & 11.07 & Tenmile Creek at Green Meadow Drive, at Helena & 2.87 & 5.43 & 5.43 & 16.8 \\
\hline 50 & 11.79 & Tenmile Creek at McHugh Lane, near Helena & 1.57 & 3.42 & 3.42 & 17.0 \\
\hline 51 & 11.80 & Helena Valley Canal Siphon at McHugh Lane, near Helena & 0 & 0 & 0 & 0 \\
\hline 52 & 12.73 & Tenmile Creek at Valley Forge Road, near Helena & .45 & 2.47 & 2.47 & 16.2 \\
\hline 53 & 13.72 & Tenmile Creek at Interstate Highway 15 , near Helena & 0 & .6 & .6 & 12.0 \\
\hline 54 & 15.30 & Tenmile Creek above Prickly Pear Creek, near Helena & 1.80 & .55 & .53 & 11.4 \\
\hline
\end{tabular}

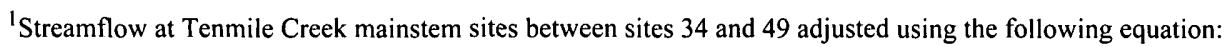

Adjusted streamflow at site $\mathrm{i}=$ Measured streamflow at site $\mathrm{i}-2.8 \times(11.07$ - Distance from Tenmile Water Treatment Plant $) / 11.07$.

${ }^{2}$ Streamflow for Tenmile Creek above Sweeney Creek assumed to be equal to streamflow measured at site 37 minus the sum of the streamflow measured at sites 35 and 36 .

${ }^{3}$ Streamflow for Tenmile Creek above Colorado Gulch assumed to be equal to streamflow measured at site 40 minus streamflow measured at site 39 .

${ }^{4}$ Streamflow for Tenmile Creek below the ditch assumed to be equal to measured streamflow at site 44 minus streamflow at site 45 .

${ }^{5}$ Streamflow for Tenmile Creek below the return flow ditch assumed to be equal to measured streamflow at site 46 plus measured streamflow at site 47 .

${ }^{6}$ Streamflow for Tenmile Creek above Sevenmile Creek assumed to be equal to streamflow for Tenmile Creek below the return flow ditch at site 47. Streamflows for Tenmile Creek below Sevenmile Creek assumed to be equal to streamflow for Tenmile Creek above Sevenmile Creek plus measured streamflow at Sevenmile Creek. 

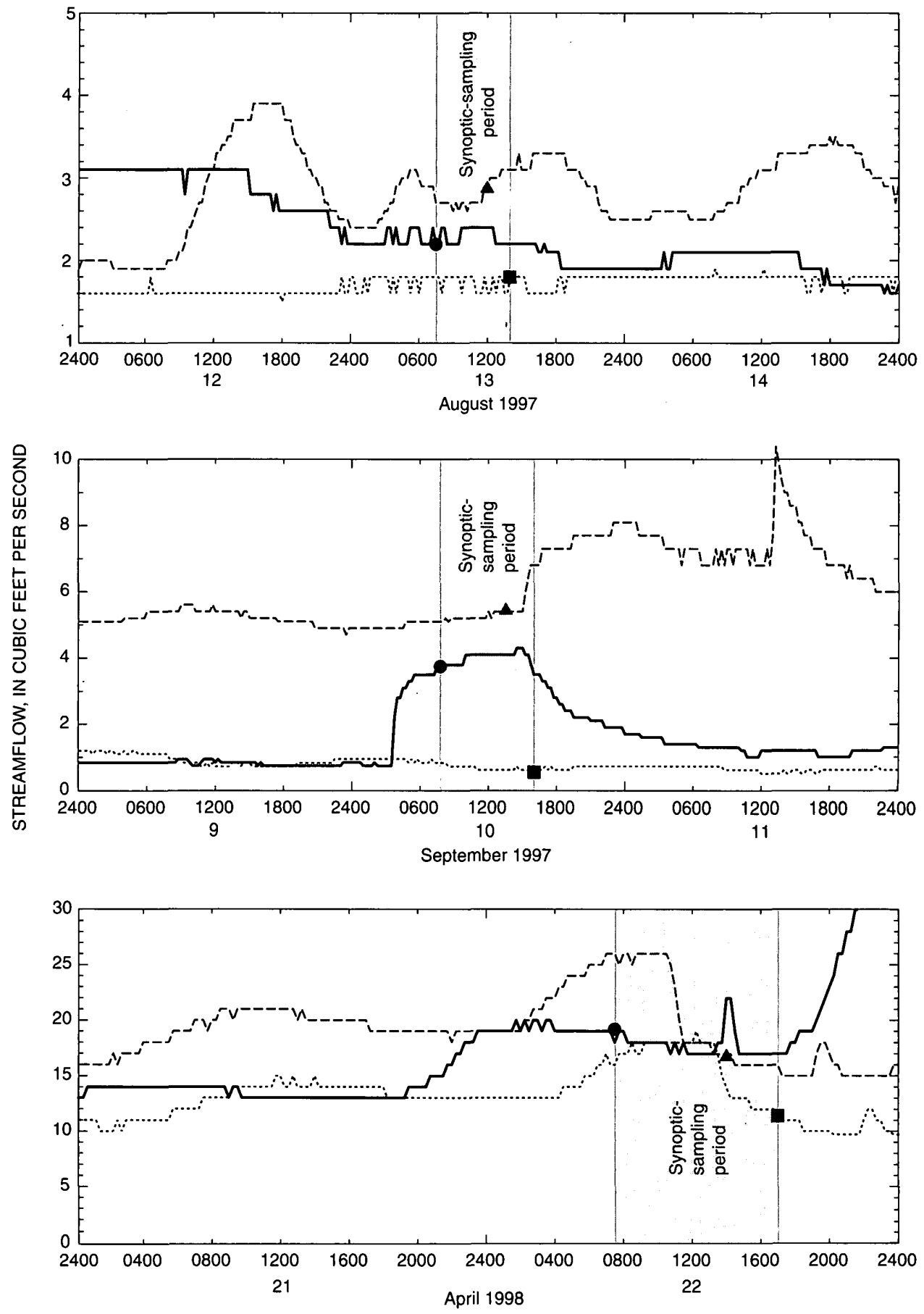

EXPLANATION

\begin{tabular}{llll}
\multicolumn{2}{c}{ RECORDED FLOW: } & \multicolumn{2}{c}{ MEASURED FLOW: } \\
\hline & Site 34 & - & Site 34 \\
$-\cdots-$. & Site 49 & A & Site 49 \\
$\ldots . .$. & Site 54 & D & Site 54
\end{tabular}

Figure 6. Comparison of recorded streamflow to synoptic streamflow measurements at selected sites, lower Tenmile Creek, Montana. 
the synoptic period at site 34 , at the upstream end of the study reach, was not evident at site 54 , at the downstream end of the study reach. Minor flow variations occurred during the synoptic period at site 49. Thus, site-to-site flow differences resulting from unsteady flow conditions were considered to be small for the August 1997 set of synoptic measurements, and no flow adjustments were necessary.

In contrast to the August 1997 synoptic period, streamflow was unsteady at site 34 on September 10, 1997. Figure 6 indicates that the streamflow measurement at site 34 was near the peak of a pulse in streamflow, possibly resulting from the closure of an upstream diversion inlet. When streamflow was measured at site 49 , the pulse had not yet arrived. Figure 6 also indicates that the pulse did not reach site 54 , where streamflow remained nearly constant throughout the day. Differences in measured streamflow from site 34 to site 49 are thus less than the differences would have been if streamflows had remained steady at site 34 , and flow adjustments were needed, as described in the following paragraph. From site 49 to site 54, flow differences resulting from unsteady flow conditions were considered to be small for the September 1997 set of synoptic measurements, and no flow adjustments were necessary.

To account for unsteady flow conditions from sites 34 through 48, streamflow was adjusted to assumed conditions before the arrival of the flow pulse (fig. 6). Thus, based on figure 6, the measured flow at site 34 ( 3.75 cubic feet per second) was decreased by 2.8 cubic feet per second to approximate steady flow conditions before the flow pulse. At site 49, where flow was measured before the arrival of the flow pulse, no adjustment to measured flow was made to account for unsteady flow effects. For each mainstem measurement site between site 34 and site 49 , the flow adjustment to the measured flow was varied, from -2.8 to 0.0 cubic feet per second, based on distance downstream from site 34 (table 3 ) to incrementally remove the effect of the flow pulse by uniformly distributing the magnitude of the flow pulse over the study reach. The equation used to calculate adjusted streamflow for any site, $\mathrm{i}$, in the 11.07 mi reach between sites 34 and 49 is the following:

Adjusted streamflow at site $\mathrm{i}=$ Measured streamflow at site $\mathrm{i}-2.8$ $\mathrm{x}$ (11.07 - Distance from Tenmile Water Treatment Plant)/11.07
For example, adjusted streamflow at site 38 , located 2.52 mi downstream from the Tenmile Water Treatment Plant was calculated by subtracting 2.8 times the ratio [(11.07-2.52)/11.07], or 2.2, from the measured streamflow. Adjusted streamflow for site 38 for September 10, 1997, thus, is 5.67 cubic feet per second minus 2.2 cubic feet per second, or 3.5 cubic feet per second.

On April 22, 1998, streamflow at site 34 was fairly steady for several hours before and after the synoptic measurement (fig. 6). However, streamflow increased by about 6 cubic feet per second at site 34 near the end of the day on April 21. Streamflow also increased downstream at site 49 by about 7 cubic feet per second and at site 54 by about 5 cubic feet per second during the early morning of April 22. By the time synoptic measurements were made at these downstream sites, streamflow had decreased to about the same values as before the increase. Streamflow increases followed by decreases might indicate a flow pulse moving through the reach. However, streamflow at site 34 did not decrease. Streamflow remained relatively steady at this site for several hours after the measurement and then increased near the end of the day on April 22. The fact that streamflow at site 34 did not decrease again after the initial increase suggests that the flow decreases at the downstream stations were the result of a flow diversion between site 34 and site 49 that began on the morning of April 22. On that basis, unsteady flow conditions probably did not significantly affect the results of the April 1998 set of synoptic streamflow measurements, and no flow adjustments were necessary.

The results of the synoptic streamflow measurements are shown graphically in figure 7 . Measured and adjusted flows can be used to infer, in a general way, how tributary inflow, diversions, and seepage affect flow in lower Tenmile Creek during the irrigation season. Abrupt changes in mainstem flow over a short reach are indicative of tributary inflows or diversions. Changes over longer reaches represent the cumulative effects of all intervening gains or losses. For the synoptic measurements made on August 13, 1997 and April 22, 1998, the error was assumed to be \pm 10 percent of the measured streamflow because the effects of unsteady flow conditions were considered to be negligible. For the synoptic measurements on September 10,1997 , the error was assumed to be \pm 25 percent of the adjusted streamflow for the reach from site 34 to 


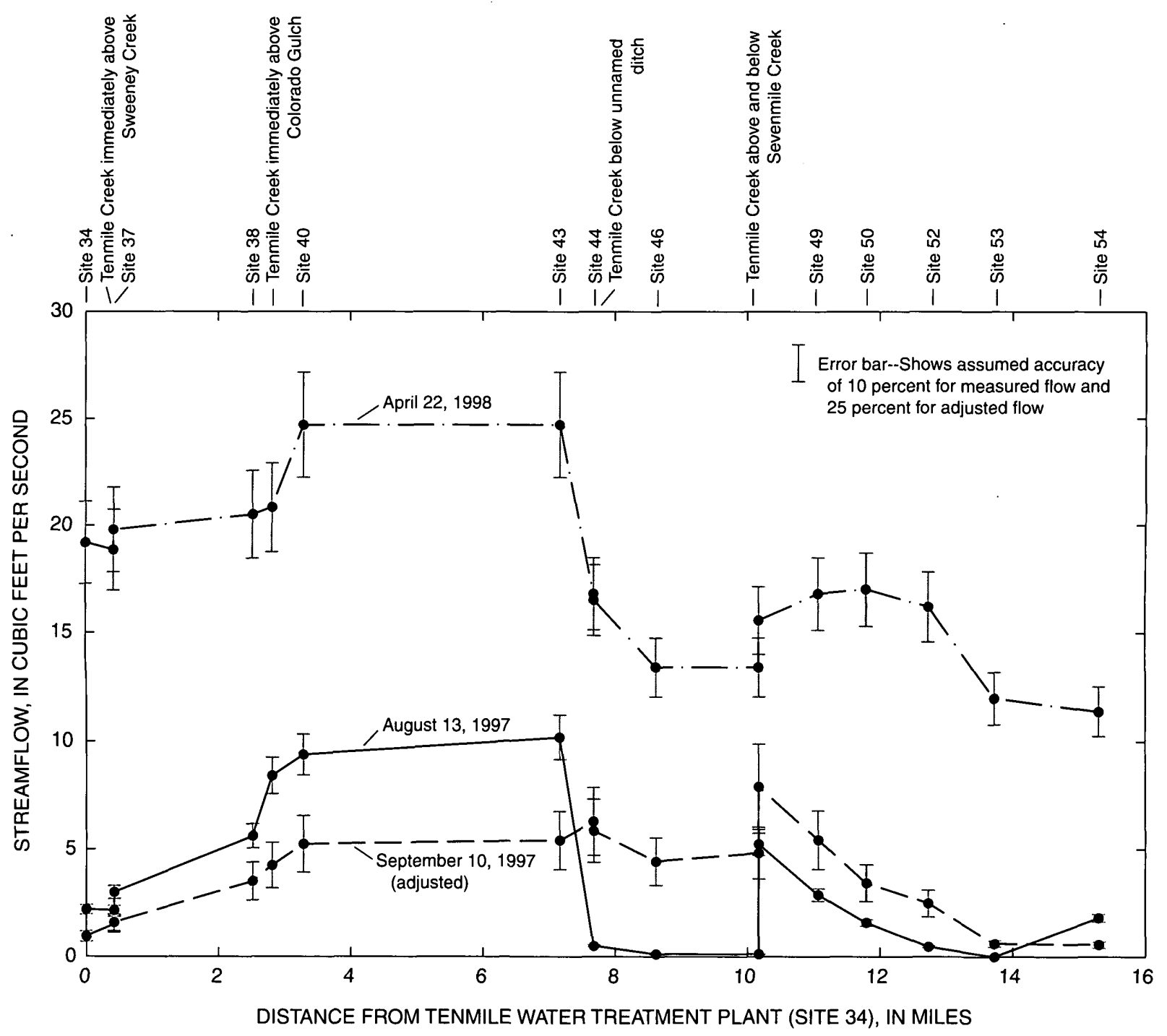

Figure 7. Synoptic streamflow measurements and adjusted streamflow at selected sites on lower Tenmile Creek, Montana, 1997 and 1998.

site 49 where flow conditions were unsteady. From site 49 to site 54 , the error was assumed to be \pm 10 percent of the measured streamflow because the effects of unsteady flow conditions were considered negligible because either the flow pulse had not yet arrived, or it had already passed and flows had returned to pre-pulse levels.

Because the error ranged from \pm 10 to \pm 25 percent, small changes in flow from site to site may not indicate real gains or losses in streamflow in Tenmile Creek. For example, the small gain in flow from Ten- mile Creek below Sevenmile Creek (site 48) to site 49 shown in figure 7 for the synoptic measurements on April 22, 1998, may not indicate a real gain. Likewise, the losses in flow from the mainstem below site 48 to site 49 for measurements on August 13, 1997 and September 10, 1997 may not be real losses. However, substantial changes in flow that consistently occur over longer reaches probably represent real gains and losses to Tenmile Creek streamflow. For example, all sets of synoptic measurements indicate a substantial decrease in flow from site 49 to site 53 . These decreases indicate streamflow losses to the cumulative effects of numer- 
ous small diversions or to seepage or both. Likewise, all sets of synoptic streamflow measurements indicate that streamflow probably increases slightly from site 34 to site 38 upstream from the mouth of Colorado Gulch. From site 38 to site 40 below Colorado Gulch, flow increases substantially, probably as a result of both tributary flow and ground-water inflow. From site 40 to site 43, flows in Tenmile Creek were nearly constant during all sets of synoptic streamflow measurements, with the intervening tributaries (sites 41 and 42) contributing no surface flow during any of the synoptic periods. Overall, the synoptic streamflow measurements indicated that gains in Tenmile Creek streamflows primarily are the result of tributary flows and losses primarily are the result of diversions. The synoptic measurements also helped indicate where flow changes significantly between the streamflow-gaging stations during the irrigation season.

\section{WATER QUALITY}

\section{Data-Collection Methods}

Surface-water quality samples were collected at six sites in the lower Tenmile Creek watershed. Five of the sites were on Tenmile Creek and one was located at the mouth of Sevenmile Creek (fig. 2).

Samples were collected four times over a 5month period in 1997-three times for analysis of major ions, nutrients, trace elements, and suspended sediment, and one time for herbicide analysis. Each site was sampled during high-flow conditions from spring runoff on June 4-5; low-flow conditions on August 27-28 (irrigation season); low-flow conditions on September 15 (late irrigation season, for herbicide sampling); and low-flow conditions on October 8-9 (post-irrigation season).

Water samples were collected either by depthand width-integration methods at multiple stream verticals according to methods described by Knapton (1985), Edwards and Glysson (1988), and Ward and Harr (1990), or by grab sampling at sites where streamflow was small and well mixed. Water-quality sampling equipment consisted of standard USGS depthintegrating polyethylene U.S. DH-81 hand-held samplers with a nylon nozzle, and a polyethylene churn splitter. Grab samples were collected directly in a polyethylene churn splitter. Suspended-sediment samples were collected in glass bottles using a U.S. DH-48 hand-held sediment sampler.

Streamflow was measured at each site at the time the samples were collected in June and August 1997. Stage-discharge relationships were used to determine streamflow at the time the samples were collected during September and October 1997.

Field measurements of water-quality properties were performed according to standard methods described by Knapton (1985). Specific conductance, $\mathrm{pH}$, and water temperature were measured onsite. Bottles and equipment were cleaned and prepared in the laboratory, and samples were processed, filtered $(0.45 \mu \mathrm{m})$, and preserved in the field as described by Horowitz and others (1994).

Water samples collected at all six sites were analyzed for concentrations of dissolved major ions, nutrients, selected dissolved and total-recoverable trace elements, and suspended sediment. Concentrations of major ions, nutrients and dissolved and total-recoverable trace elements were determined by the Montana Tunnels Water Quality Laboratory. Table 4 (back of report) lists the analytical methods and minimum reporting levels (U.S. Environmental Protection Agency, 1983; Montana Tunnels Mining, Inc., 1997) for these constituents. Tables 5 and 6 (back of report) list the field-measured parameters and concentrations of major ions, nutrients, and trace elements in lower Tenmile Creek and Sevenmile Creek. Aluminum, chromium, iron, manganese, nickel, silver, and zinc were analyzed by inductively coupled plasma-mass spectroscopy. Arsenic, cadmium, copper, lead, and selenium were analyzed by graphite-furnace atomic absorption. Mercury was analyzed by flow-injection cold vapor/hydride.

Suspended-sediment samples were analyzed for concentration and percentage of suspended sediment finer than 0.062-mm diameter (silt size and smaller) at the USGS sediment laboratory, Helena, Mont. Methods for sediment analysis are described by Lambing and Dodge (1993).

Water samples collected at two streamflowgaging stations $(06064100$, site 49 , and 06064150 , site 54) were analyzed for herbicides. The concentrations of chlorophenoxy herbicides were determined by the Montana Department of Public Health and Human Services, Laboratory Services Bureau, Helena, Mont. Sample bottles and preservatives were provided by the analytical laboratory. Table 4 lists the analytical method (U.S. Environmental Protection Agency, 1991) 
and minimum reporting levels (U.S. Environmental Protection Agency, 1983) for chlorophenoxy herbicides.

\section{Quality Assurance}

Data-collection and analytical procedures used in this study incorporated practices designed to control and assess the quality of sample data. Methods and associated quality control for collection and processing of water samples are described by Knapton (1985), Knapton and Nimick (1991), and Horowitz and others (1994). Standard quality-assurance procedures used by the Montana Tunnels Water Quality Laboratory are described by Montana Tunnels Mining, Inc. (1997). The Montana Tunnels Water Quality Laboratory provided the results of quality-control analyses performed within their facilities.

Bottles and preservatives for water samples were provided by Maxim Technologies, Helena, Mont. Standard solutions for calibration of $\mathrm{pH}$ and specificconductance meters were provided by the USGS National Water Quality Laboratory (NWQL).

The effectiveness of quality-assurance practices is measured by quality-control data that document possible sample contamination and reproducibility of analytical results. These data were provided by analyses of test samples that consisted of either a field-blank sample of deionized water or a replicate environmental sample included with other environmental samples for laboratory analysis. A field-blank sample of deionized water is treated as an environmental sample in all aspects, including exposure to sampling equipment, sample containers, filtration apparatus, chemical preservatives in the field, holding times, and laboratory processing. A replicate environmental sample is a volume of sampled material split into subsamples in such a manner that the physical and chemical characteristics of each subsample are considered to be essentially identical in composition.

Quality-control samples composed about 30 percent of the total number of water samples submitted for analysis. Quality control for water analyses consisted of four replicate samples and two field-blank samples for all analytes (except herbicides), one field-blank sample for all analytes except selenium and herbicides, and four field-blank samples for selected analytes. Analytical results for the quality-assurance/qualitycontrol samples are presented together with results for environmental samples in tables 5 and 6.
A blank sample with constituent concentrations equal to or less than the minimum reporting level (typical measurement precision at the detection level) for the analytical method indicates that the entire sample collection, processing, and analytical process is free of significant contamination. In general, detectable concentrations that are within two times the minimum reporting level are considered acceptable due to the limits of precision at the minimum range of the analytical method. However, if larger concentrations are detected, then the magnitude and persistence of the values might indicate contamination, which can bias the corresponding environmental sample results. A onetime occurrence is too random to isolate the source of contamination and will likely have little effect on overall bias of the database. However, persistent occurrences of detectable concentrations in blanks for the same constituent indicates that bias may be substantial and the environmental data for that constituent are suspect.

Measurable concentrations of magnesium and zinc were detected in field blanks, but only one value for magnesium exceeded twice the minimum reporting level. Dissolved magnesium concentrations in field blanks ranged from $<0.1$ to $0.3 \mathrm{mg} / \mathrm{L}$ (table 5); the minimum reporting level for dissolved magnesium is $0.1 \mathrm{mg} / \mathrm{L}$ (table 4). The lowest dissolved magnesium concentration reported for all the environmental samples was $1.2 \mathrm{mg} / \mathrm{L}$, or 4 times the highest concentration reported for a field blank. Dissolved magnesium concentrations for all environmental samples collected in October exceeded $3 \mathrm{mg} / \mathrm{L}$, and presumably were free of significant bias.

Field-blank samples had dissolved zinc concentrations that ranged from $<10$ to $50 \mu \mathrm{g} / \mathrm{L}$ and totalrecoverable concentrations that ranged from $<10$ to 100 $\mu \mathrm{g} / \mathrm{L}$. Field-blank samples collected for this study consistently had dissolved zinc concentrations higher than the original minimum reporting level of $10 \mu \mathrm{g} / \mathrm{L}$ (table 4). Based on a series of blank samples tested in October 1997, the elevated zinc concentrations were attributed to vials containing nitric acid sample preservative. Evidently, the amount of zinc varied between the vials, as some environmental samples preserved with nitric acid contained no detectable zinc. Zinc concentrations in environmental samples that were less than the maximum concentration found in any field blank $(100 \mu \mathrm{g} / \mathrm{L})$ may be unreliable. Therefore, the minimum reporting level for zinc concentration for this study was revised from 10 to $100 \mu \mathrm{g} / \mathrm{L}$ to reflect the 
loss of resolution in the range affected by contamination. Zinc-concentration data were not used to calculate zinc loads or make comparisons between sites.

\section{Properties and Concentrations}

Water-quality properties and concentrations of major ions, nutrients, trace elements, and suspended sediment are presented in tables 5 and 6 . Water in lower Tenmile Creek is a calcium bicarbonate type with relatively low concentrations of major ions and nutrients. The water is moderately alkaline, with $\mathrm{pH}$ values ranging from 7.3 to 8.6. All samples had low sodium adsorption ratios (less than 1.0), indicating a very low sodium hazard for irrigation water (U.S. Salinity Laboratory Staff, 1954).

For each sampling period, constituent concentrations generally increased in a downstream direction in lower Tenmile Creek. Concentrations of most major ions, nutrients, and suspended sediment were higher in Sevenmile Creek (site 48) than in lower Tenmile Creek throughout the range of flows sampled. Generally, concentrations of major ions were higher during lowflow (August and October) than during high-flow (June) conditions.

Concentrations of some trace elements varied spatially, while concentrations of other trace elements showed little spatial variation. Total-recoverable arsenic concentrations were similar throughout lower Tenmile Creek and in Sevenmile Creek (range of 10 to $21 \mu \mathrm{g} / \mathrm{L}$ ). Total-recoverable cadmium concentrations generally were similar throughout lower Tenmile Creek during high-flow conditions and decreased downstream during low flow. Total-recoverable cadmium concentrations in Sevenmile Creek were below the minimum reporting level. Total-recoverable copper concentration varied the most in October, when concentrations decreased downstream in lower Tenmile Creek to the confluence with Sevenmile Creek. The relatively elevated total-recoverable copper concentration $(31 \mu \mathrm{g} / \mathrm{L}$ ) in Sevenmile Creek (site 48) in October caused an increase in concentration in Tenmile Creek at sites 49 and 54. Like arsenic, concentrations of totalrecoverable lead varied little between sites (range of $<3$ to $10 \mu \mathrm{g} / \mathrm{L}$ ). Concentrations of total-recoverable iron and manganese showed a spatial pattern similar to that of copper.

At-site concentrations of some trace elements also varied with streamflow. At most mainstem sites, total-recoverable aluminum, total-recoverable and dis- solved cadmium, and total-recoverable lead concentrations were higher during high-flow (June) conditions than during low-flow (August and October) conditions. Dissolved copper and total-recoverable iron concentrations were highest during high-flow conditions in June and lowest during low-flow conditions in August at most sites. Total-recoverable arsenic, copper, and manganese concentrations showed no consistent trend from high-flow to low-flow conditions at most sites. At the mainstem site farthest upstream, Tenmile Creek at the Tenmile Water Treatment Plant (site 34), totalrecoverable and dissolved concentrations of cadmium and copper and total-recoverable concentrations of iron were highest during low-flow conditions in October.

To understand how metals are partitioned between the dissolved and particulate phases, both total-recoverable and dissolved concentrations of cadmium, copper, and lead were analyzed. Dissolved cadmium accounted for about 25 to 85 percent of the totalrecoverable cadmium concentration in most samples, with the highest percentages occurring during low-flow conditions in October. In contrast, dissolved copper accounted for about 44 to 88 percent of the total-recoverable copper in June, whereas in October dissolved copper accounted for about 3 to 67 percent of the totalrecoverable copper. Dissolved lead was not detected in any sample, although in June two total-recoverable lead concentrations were about 3 times the detection limit.

Results in table 6 indicate that suspendedsediment concentrations generally were low (range of 2 to $42 \mathrm{mg} / \mathrm{L}$ ), resulting in relatively clear water at most sites. Suspended-sediment concentrations typically were highest during high-flow conditions.

Herbicides are applied in the Helena Valley primarily in June and in the middle of September (Donna Rise, Montana Department of Agriculture, oral commun., 1997). To maximize the likelihood of detection, lower Tenmile Creek was sampled when streamflow was relatively low, rather than during the June application period, when high streamflow might have diluted herbicides. Analyses for chlorophenoxy herbicides in water from two sites (49 and 54) resulted in no detectable concentrations of any compound. Table 4 lists the herbicides for which samples were analyzed, the minimum reporting levels, and applicable drinking-water standards. The analytes include products commonly used by homeowners (dicamba), county weed districts and commercial weed sprayers (2,4-D, MCPA, and picloram), and farmers and ranchers (2,4-D, dicamba, 
MCPA, and picloram) (David Rise, Montana Department of Agriculture, written commun., 1997).

\section{Comparison to Water-Quality Standards}

Some constituents in water can pose health risks to humans or aquatic organisms through either acute or chronic toxicity. Although lower Tenmile Creek is not a source of public drinking-water supply, seepage from the stream contributes some recharge to the valley-fill aquifer system that is the sole source of domestic water supply for about 13,000 residents of the Helena Valley (Briar and Madison, 1992). Therefore, it is useful to compare the water-quality results in tables 5 and 6 to State of Montana water-quality standards for human health (Montana Department of Environmental Quality, 1995), which have been established for fluoride, nitrite, nitrate, and 11 of the trace elements that were analyzed in samples from lower Tenmile Creek (table 4). Concentrations that equalled or exceeded Montana human-health standards, except for iron and manganese whose standards are aesthetic, are highlighted with shading in table 6 .

Concentrations of fluoride, nitrite, or nitrate in water from lower Tenmile Creek did not exceed standards for human health. The minimum reporting level of $0.6 \mu \mathrm{g} / \mathrm{L}$ for mercury was greater than the standard of $0.14 \mu \mathrm{g} / \mathrm{L}$, thus precluding the determination of exceedances for mercury.

Total-recoverable arsenic concentrations were near, and occasionally exceeded, the State humanhealth standard of $18 \mu \mathrm{g} / \mathrm{L}$ for drinking water (table 6 and fig. 8). Total-recoverable arsenic concentrations varied only slightly between sites, ranging from 10 to

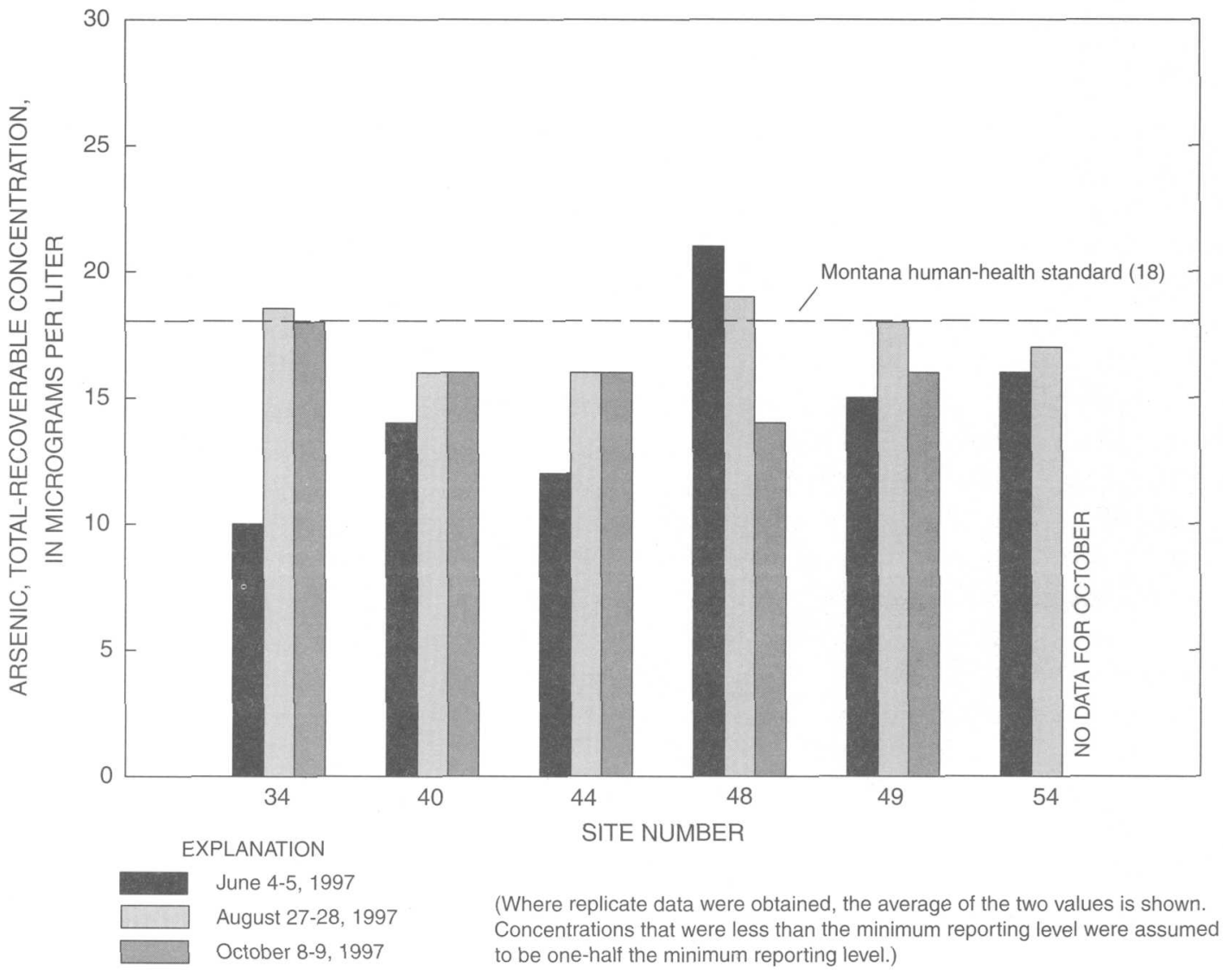

Figure 8. Total-recoverable arsenic concentration at selected mainstem sites $(34,40,44,49$, and 54 ) and Sevenmile Creek (site 48), a tributary, in the lower Tenmile Creek watershed, Montana, 1997, compared to the State of Montana human-health standard for drinking water (Montana Department of Environmental Quality, 1995). 
$21 \mu \mathrm{g} / \mathrm{L}$. Most of these concentrations were near the human-health standard for drinking water of $18 \mu \mathrm{g} / \mathrm{L}$ (fig. 8). For dates where duplicate samples were obtained, concentrations of arsenic shown in figure 8 are averages of the sample analyses.

State of Montana aquatic-life standards for acute and/or chronic toxicity (Montana Department of Environmental Quality, 1995) have been established for chloride, ammonia, the herbicide pentachlorophenol, and 12 of the trace elements that were analyzed in samples collected from lower Tenmile Creek (table 4). Acute toxicity is manifested by widespread death of aquatic organisms within a relatively short time as a result of rapid and large increases in constituent concentrations. Chronic toxicity is manifested by suppression of normal biological functions over a long time as a result of constituent concentrations that consistently exceed biological thresholds for impairment. Chronic toxicity does not cause death directly but can affect the growth, reproduction, or other biological activities necessary to sustain a healthy population of aquatic organisms. The degree of toxicity to aquatic life caused by cadmium, chromium III, copper, lead, nickel, silver, and zinc varies with the ambient hardness of the water (U.S. Environmental Protection Agency, 1986). Thus, toxicity thresholds for these trace elements are specific to each sample and are calculated from equations presented in table 7 (back of report).

Concentrations of chloride, ammonia, arsenic, chromium, iron, nickel, and selenium (tables 5 and 6) did not exceed aquatic-life standards in any of the samples. In contrast, total-recoverable concentrations of cadmium, copper, lead, and zinc exceeded aquatic-life standards for chronic toxicity in several samples. In addition, the acute toxicity standard for copper was exceeded in at least one sample from every site on Tenmile Creek. A similar pattern may have occurred for zinc, but this possibility cannot be determined conclusively due to zinc contamination that affected some samples. Concentrations listed in table 6 that equal or exceed standards for chronic toxicity are in boldface; values that also equal or exceed standards for acute toxicity (if applicable) are in bold italics. If the minimum reporting level was greater than the chronic toxicity standard, then the exceedances could not be determined, and the trace-element concentration reported in table 6 is footnoted accordingly.

The spatial and seasonal variation of concentrations of cadmium, copper, and lead and comparisons to aquatic-life standards are displayed graphically in fig- ures 9-11. Concentrations of total-recoverable cadmium, copper, and lead exceeded the standard for chronic toxicity in June at every Tenmile Creek site, but not at Sevenmile Creek (site 48). Concentrations of these trace metals also were nearly equal to or exceeded the standards for chronic toxicity in August and October at the two upstream sites ( 34 and 40). In October, total-recoverable copper concentrations in Tenmile Creek exceeded the standard for chronic toxicity for sites $34,40,48$, and 49 . Standards for acute toxicity were exceeded for copper at all Tenmile Creek sites in June and at sites 34 and 40 in October.

Aquatic-life standards have not been established for nutrients other than ammonia. However, excessive amounts of nutrients, particularly dissolved orthophosphate and total phosphorus, stimulate the growth of algae and other aquatic plants. Algal growths impart undesirable tastes and odors to water, interfere with water treatment, and contribute to eutrophication, which deprives aquatic organisms of oxygen. To prevent algal growths and to control eutrophication, the concentration of total phosphorus in streams needs to be less than $0.1 \mathrm{mg} / \mathrm{L}$ and, for streams that discharge into a lake or reservoir, the concentration needs to be less than $0.05 \mathrm{mg} / \mathrm{L}$ (U.S. Environmental Protection Agency, 1986). Phosphorus concentrations in lower Tenmile Creek from the three sites above Sevenmile Creek were consistently less than these concentrations (ranging from 0.02 to $0.03 \mathrm{mg} / \mathrm{L}$ ). However, Sevenmile Creek (site 48) had a total phosphorus concentration greater than both recommended levels $(0.15 \mathrm{mg} / \mathrm{L})$ and total phosphorus concentrations between the recommended levels in August $(0.08 \mathrm{mg} / \mathrm{L})$ and October $(0.07 \mathrm{mg} / \mathrm{L})$. Slightly elevated total-phosphorus concentrations persisted in June in Tenmile Creek downstream from the confluence with Sevenmile Creek, where concentrations were $0.05 \mathrm{mg} / \mathrm{L}$ at site 49 and $0.06 \mathrm{mg} / \mathrm{L}$ at site 54 . A combination of available nutrients and warm water due to decreased depths from dewatering and lack of riparian shade likely contribute to summer algal blooms in lower Tenmile Creek.

\section{Transport of Trace Elements}

The downstream transport of a constituent is commonly expressed as a mass of constituent (load) transported past a measuring location in a given period of time. Calculation of constituent load is a useful way to compare the relative contribution of constituent mass from streams having widely varying 

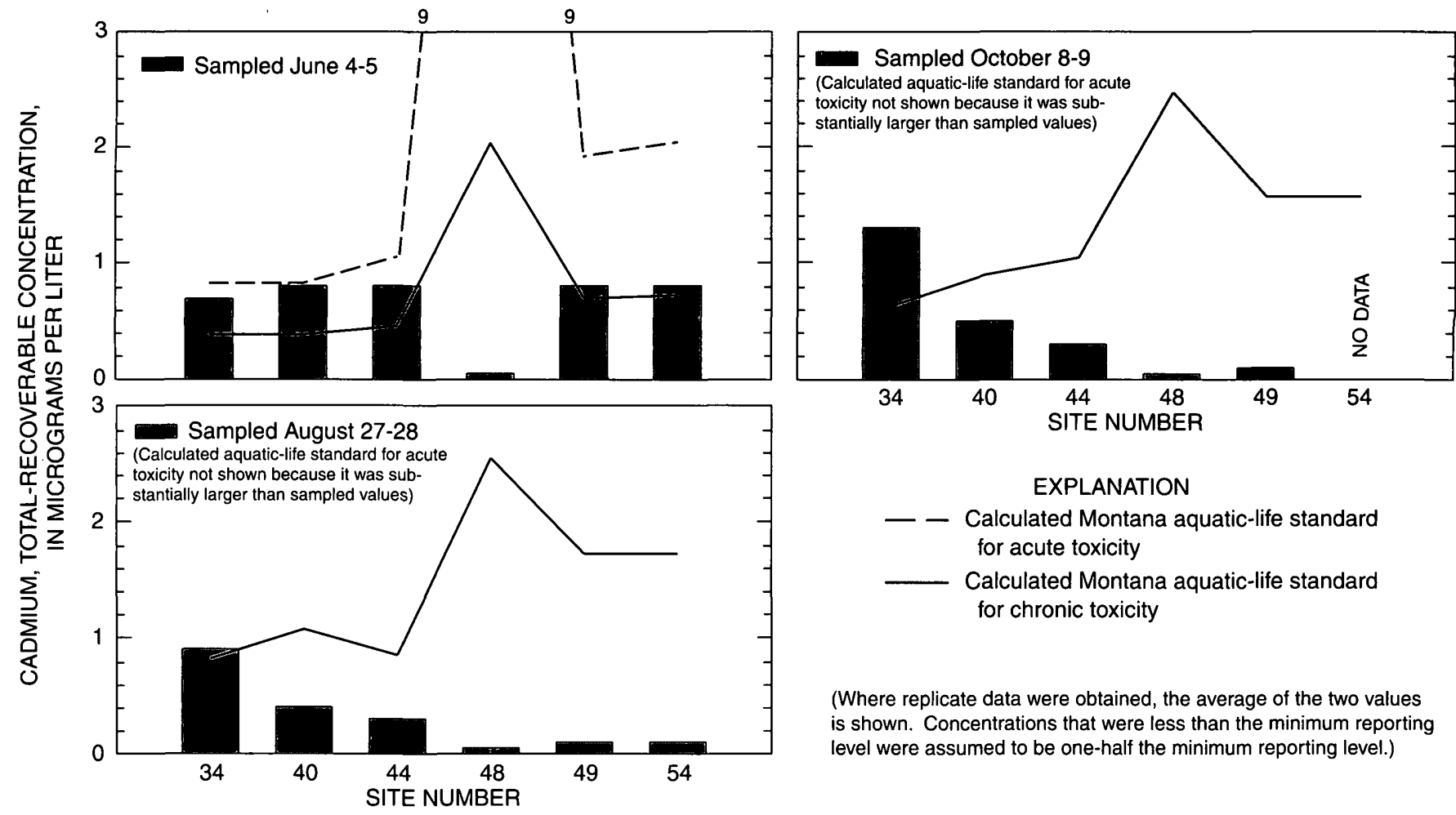

(Where replicate data were obtained, the average of the two values is shown. Concentrations that were less than the minimum reporting level were assumed to be one-half the minimum reporting level.)

Figure 9. Total-recoverable cadmium concentration at selected mainstem sites $(34,40,44,49$, and 54 ) and Sevenmile Creek (site 48), a tributary, in the lower Tenmile Creek watershed, Montana, 1997, compared to State of Montana aquatic-life standards for acute and chronic toxicity (Montana Department of Environmental Quality, 1995).

concentrations and flows. This comparison allows identification of important sources that might introduce large quantities of a constituent that can substantially affect downstream water quality. For example, tributary inflow having a very high concentration of a constituent, but a small streamflow, will have little effect on a receiving stream that has a sufficiently large flow to dilute the incoming constituent concentration. Conversely, tributary inflow having a very high concentration of a constituent and a large flow may substantially increase the constituent concentration in the receiving stream.

Instantaneous loads represent conditions only at the time of sampling. However, instantaneous loads determined for short periods of time, such as synoptic sampling episodes, may be compared between sites to qualitatively identify reaches where constituents are contributed in relatively large proportions during the hydrologic condition and season sampled. In this man- ner, important source areas for particular constituents can be identified.

Instantaneous loads were calculated as the product of total-recoverable constituent concentration (in $\mu \mathrm{g} / \mathrm{L}$ ) and streamflow (in cubic feet per second). The product was then multiplied by 0.0054 to convert to an equivalent daily transport rate (pounds per day).

Instantaneous trace-element and suspended-sediment load data expressed as daily transport rates are presented in table 8 (back of report) and shown for arsenic, cadmium, copper, lead, and suspended sediment loads in figures 12-16. For plotting purposes, instantaneous loads based on concentrations less than the minimum reporting level were calculated using one-half the minimum reporting level.

Loads of arsenic, cadmium, copper, lead, and suspended sediment vary somewhat from mainstem site to mainstem site (figs. 12-16). These variations are partly due to analytical variability, as indicated by variable concentrations for some trace elements in replicate 


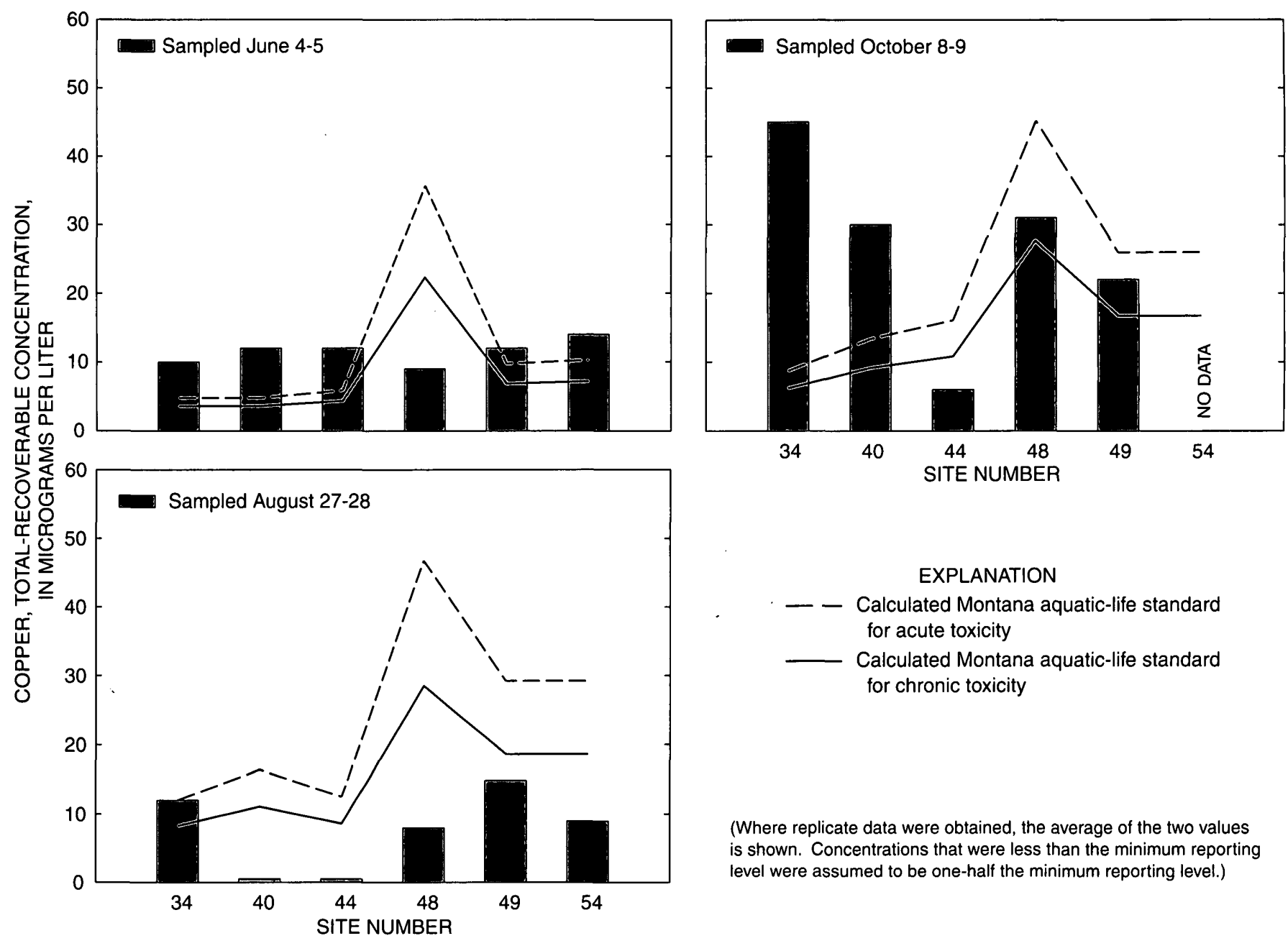

Figure 10. Total-recoverable copper concentration at selected mainstem sites $(34,40,44,49$, and 54$)$ and Sevenmile Creek (site 48), a tributary, in the lower Tenmile Creek watershed, Montana, 1997, compared to State of Montana aquatic-life standards for acute and chronic toxicity (Montana Department of Environmental Quality, 1995).

samples, and partly due to streamflow variations from site to site. Figures 12-16 indicate that the largest mass loads generally were transported during high-flow conditions in June. Even at those sites where concentrations in June were not the highest, substantially larger loads were transported in June than during the other two sampling periods, as shown for copper in figure 14. The downstream patterns in loads during August and October are complicated by load reductions caused by diversions.
During August and October, Sevenmile Creek (site 48) contributes arsenic, copper, lead, and suspended-sediment loads that are similar to or even larger than those in the mainstem. Although Sevenmile Creek contributed some trace-element load, most of the load transported to lower Tenmile Creek, especially during high flow, originated in the upper Tenmile Creek basin. 

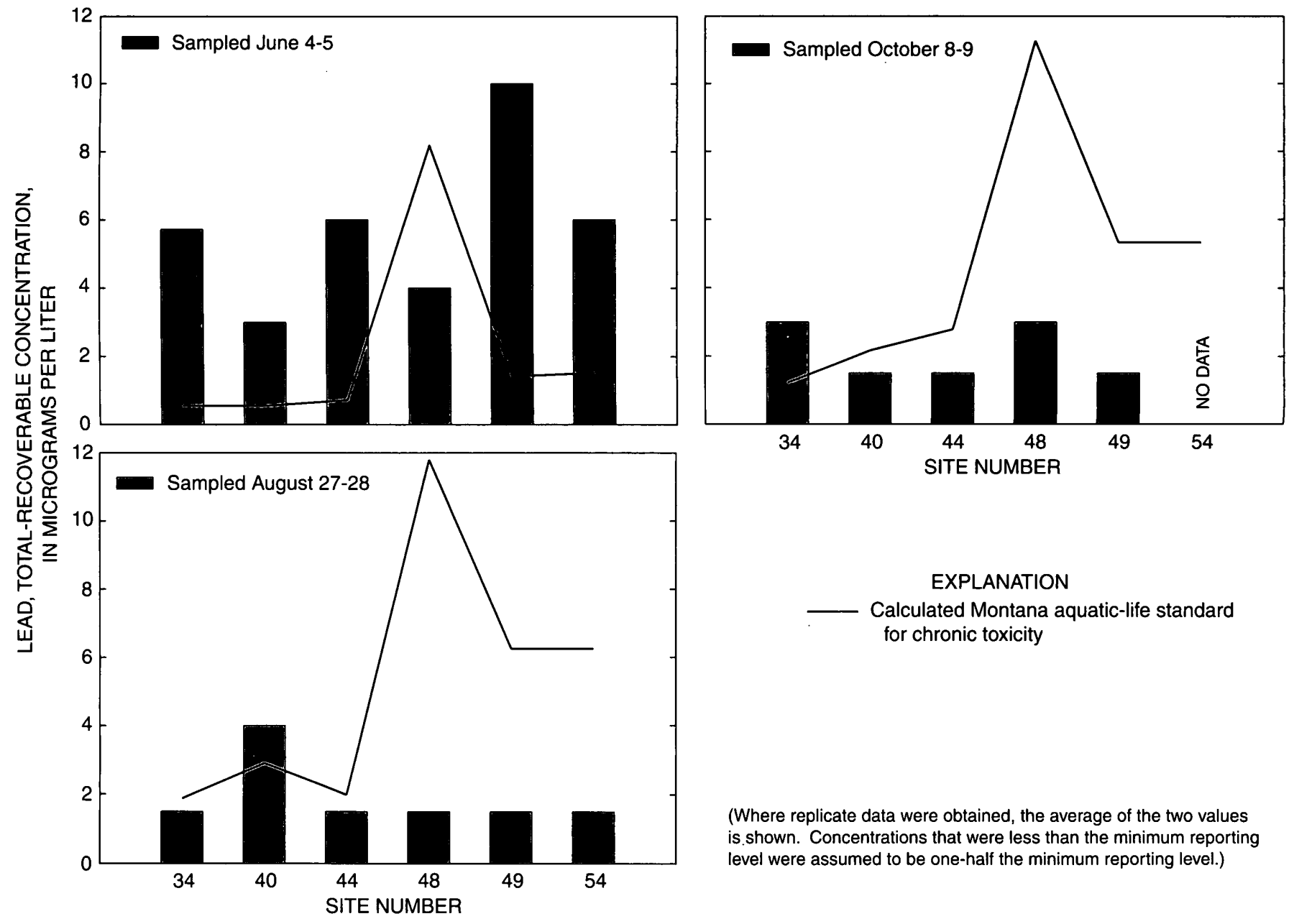

(Where replicate data were obtained, the average of the two values is shown. Concentrations that were less than the minimum reporting level were assumed to be one-half the minimum reporting level.)

Figure 11. Total-recoverable lead concentration at selected mainstem sites (34, 40, 44, 49, and 54) and Sevenmile Creek (site 48), a tributary, in the lower Tenmile Creek watershed, Montana, 1997, compared to State of Montana aquatic-life standards for chronic toxicity (Montana Department of Environmental Quality, 1995). 


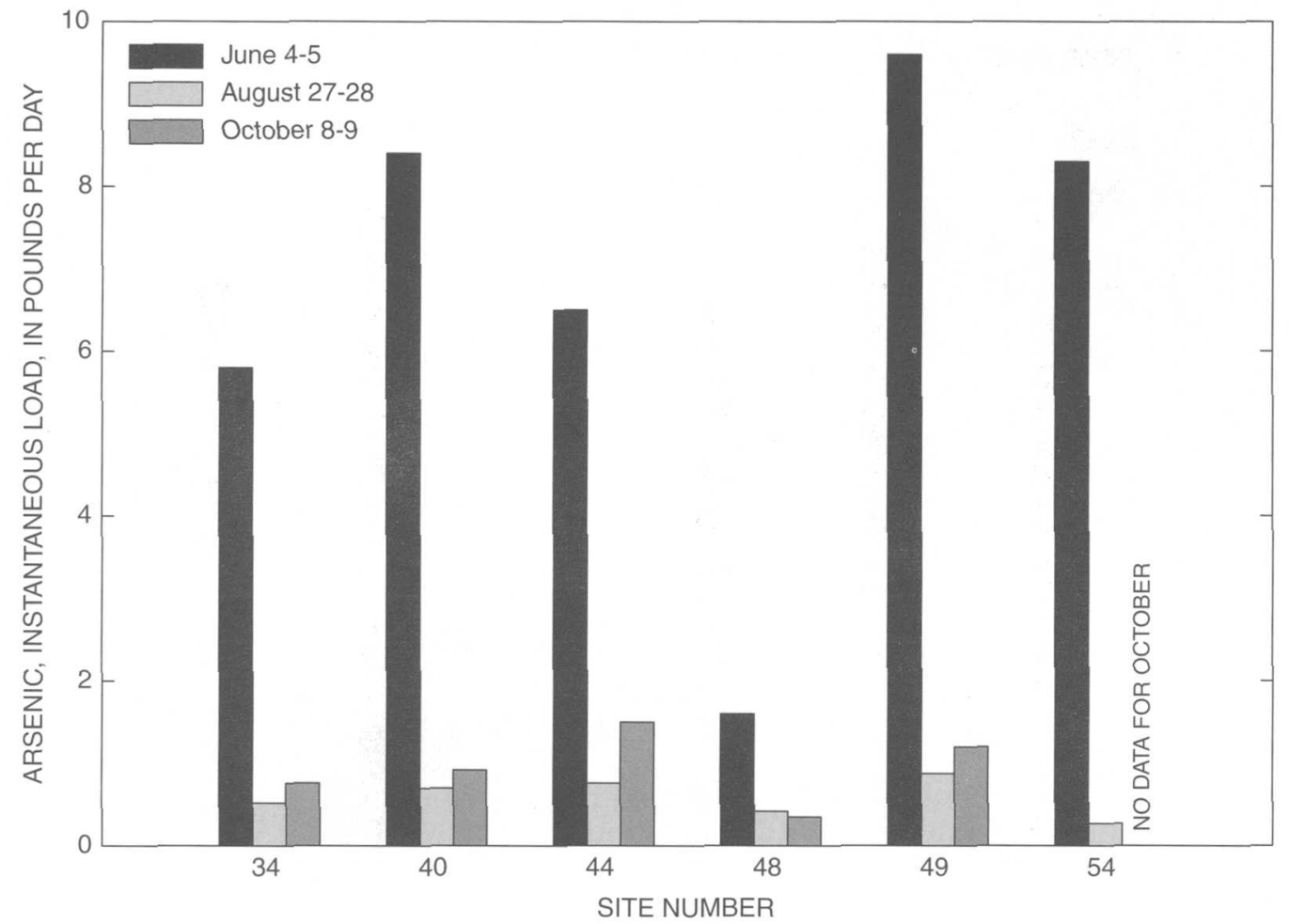

Figure 12. Instantaneous arsenic loads at selected mainstem sites (34, 40, 44, 49, and 54) and Sevenmile Creek (site 48), a tributary, in the lower Tenmile Creek watershed, Montana, 1997.

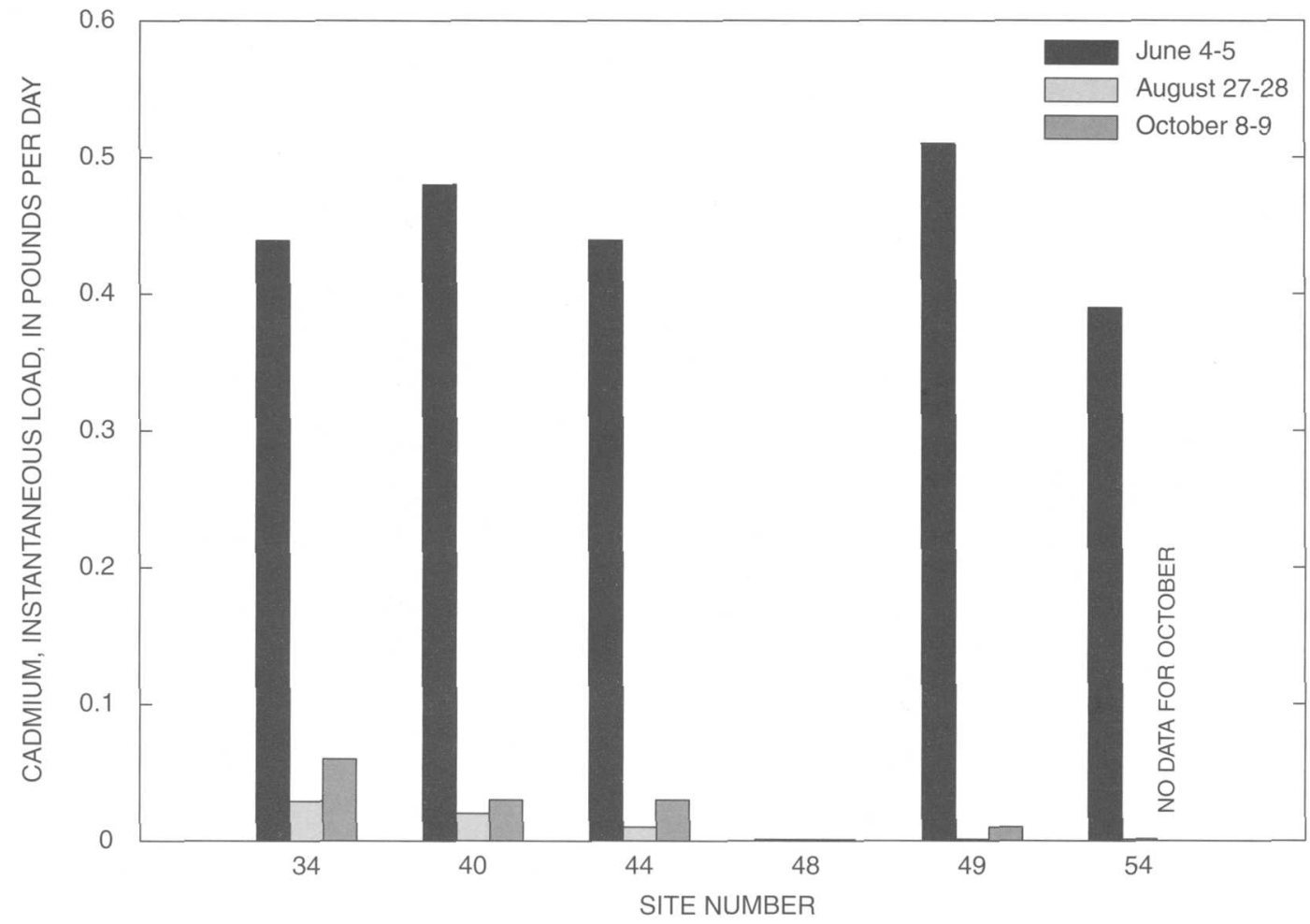

Figure 13. Instantaneous cadmium loads at selected mainstem sites (34, 40, 44, 49, and 54) and Sevenmile Creek (site 48), a tributary, in the lower Tenmile Creek watershed, Montana, 1997. Loads based on concentrations less than the minimum reporting level were calculated using one-half the minimum reporting level. 


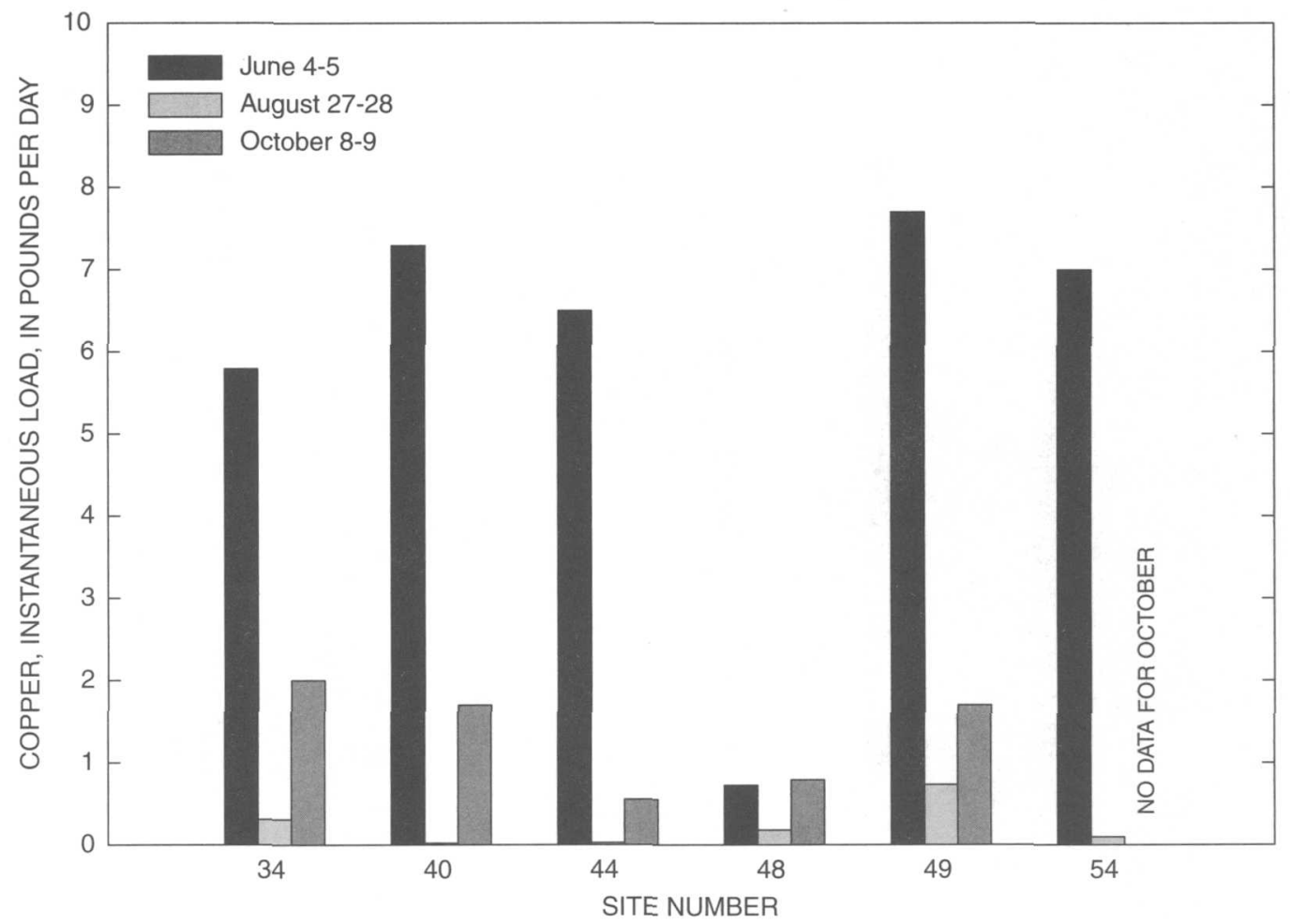

Figure 14. Instantaneous copper loads at selected mainstem sites $(34,40,44,49$, and 54) and Sevenmile Creek (site 48), a tributary, in the lower Tenmile Creek watershed, Montana, 1997. Loads based on concentrations less than the minimum reporting level were calculated using one-half the minimum reporting level.

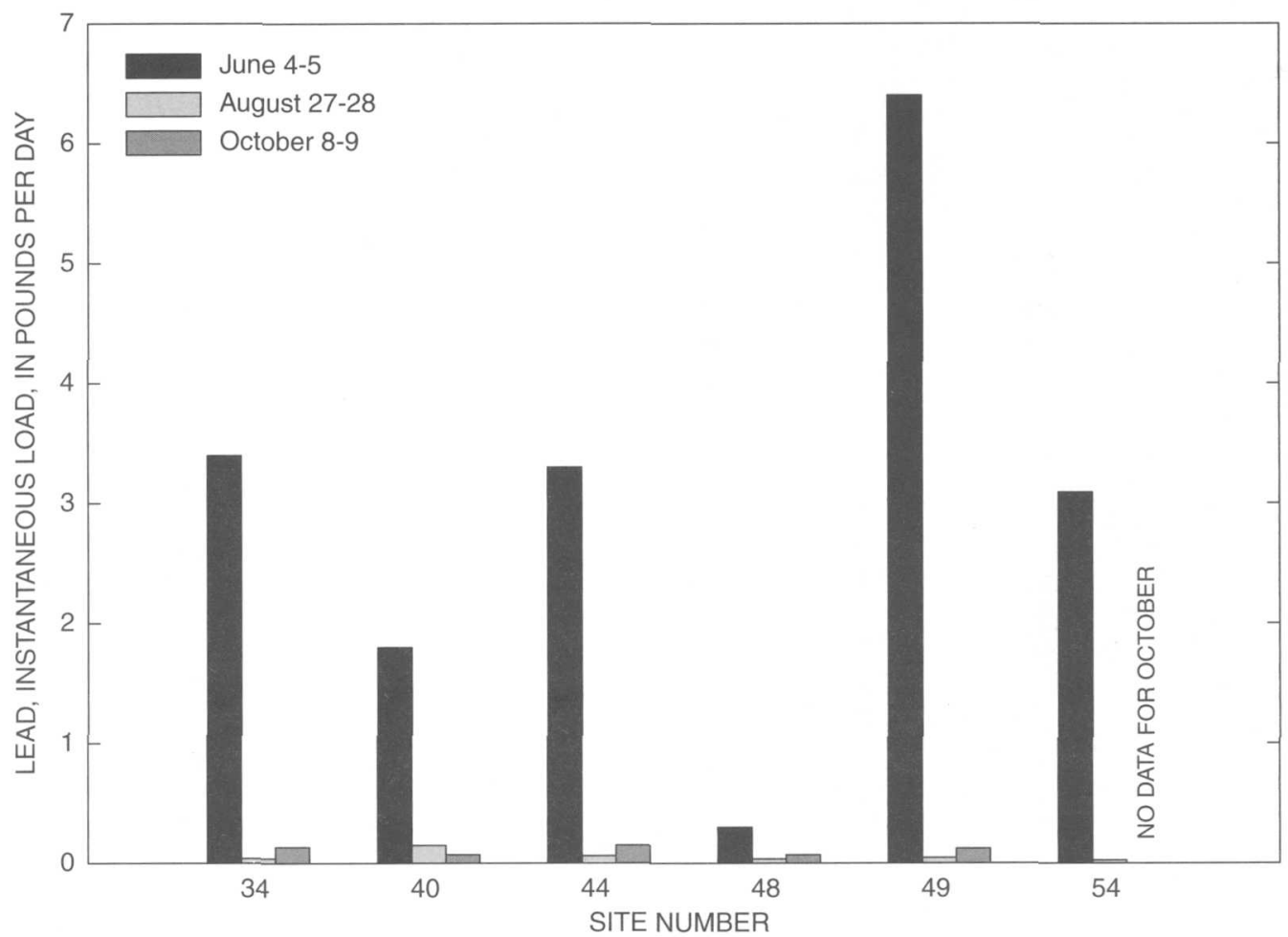

Figure 15. Instantaneous lead loads at selected mainstem sites (34, 40, 44, 49, and 54) and Sevenmile Creek (site 48), a tributary, in the lower Tenmile Creek watershed, Montana, 1997. Loads based on concentrations less than the minimum reporting level were calculated using one-half the minimum reporting level. 


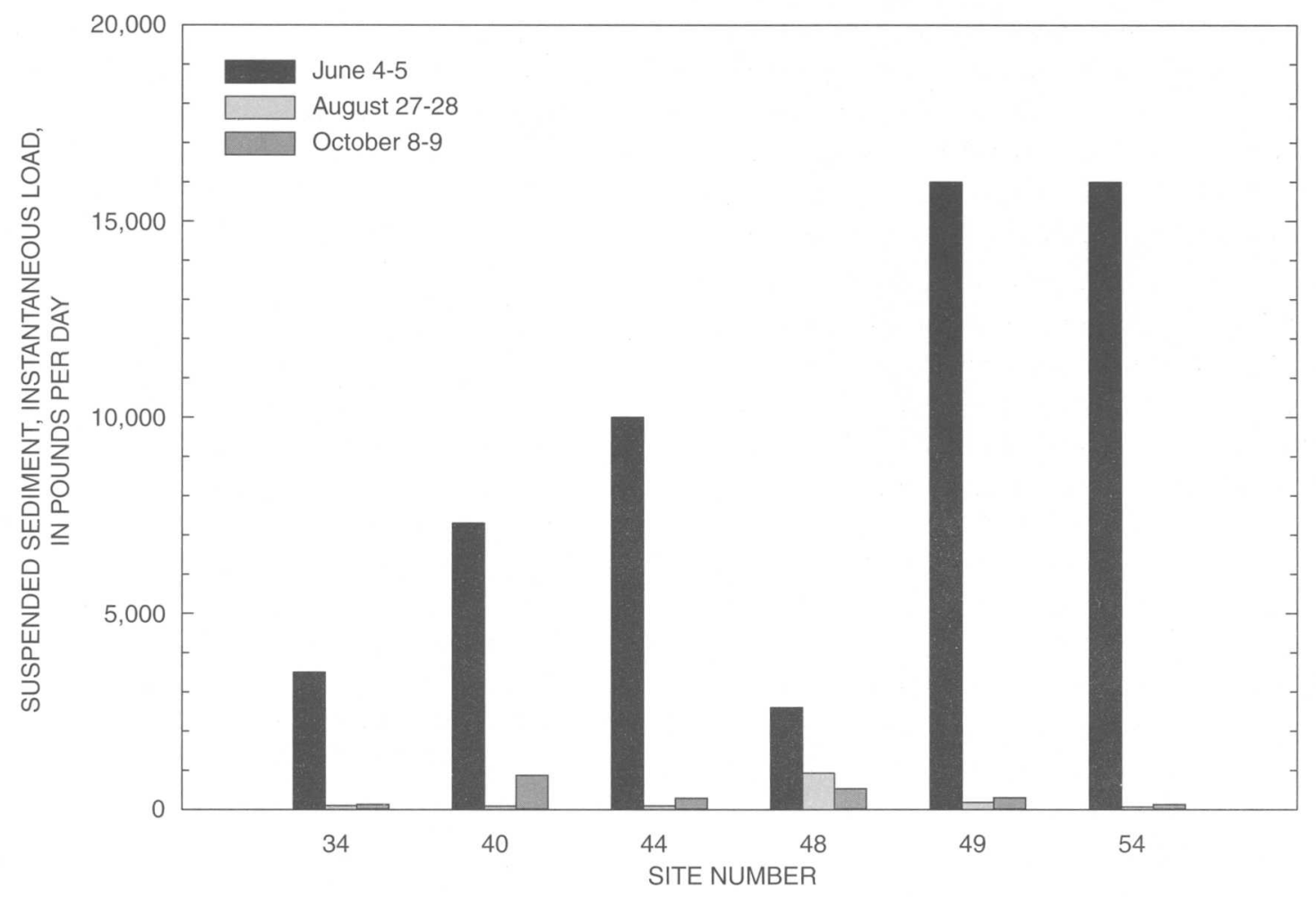

Figure 16. Instantaneous suspended-sediment loads at selected mainstem sites $(34,40,44,49$, and 54) and Sevenmile Creek (site 48), a tributary, in the lower Tenmile Creek watershed, Montana, 1997.

\section{SUMMARY}

Lower Tenmile Creek drains about 150 square miles of mountainous and valley terrain and flows about 15 miles to its confluence with Prickly Pear Creek. In 1997 and 1998, the U.S. Geological Survey, in cooperation with Lewis and Clark County and the Montana Department of Natural Resources and Conservation, conducted a reconnaissance investigation of streamflow and water quality to provide information that can be used to guide future management of the lower Tenmile Creek watershed.

Based on long-term streamflow records at two sites on Tenmile Creek, mean monthly streamflow is only slightly greater at the site in the lower watershed than at the site in the upper watershed, even though the drainage area at the lower measurement site is more than three times as large as that at the upper measurement site. The general seasonal pattern of streamflow is very similar for both sites, with largest flows occurring in May and June as a result of snowmelt and rainfall runoff, and the smallest flows occurring during late summer through winter when virtually all flow is from ground water.
Based on seasonal streamflow data obtained at four streamflow-gaging stations in the lower watershed, streamflow is variable from site to site, particularly during the irrigation season. Variations in streamflow are not always consistent and reflect complex patterns of runoff and diversion management.

To determine the location and magnitude of specific gains and losses to streamflow under different flow conditions during the irrigation season, three sets of synoptic streamflow measurements were made at 21 sites in the lower watershed. Although the results from the synoptic measurements were difficult to interpret because of somewhat unsteady flow conditions during the measurements, the measurements confirmed the general pattern of flow gains and losses shown by the streamflow-gaging station records. The synoptic measurements also indicated that gains in Tenmile Creek streamflows primarily are the result of tributary flows and losses primarily are the result of diversions.

Water-quality samples were collected from five sites on lower Tenmile Creek and one site at the mouth of Sevenmile Creek during high-flow conditions in June, irrigation-season low-flow conditions in August, 
and post-irrigation season low-flow conditions in October. All samples were analyzed for major ions, nutrients, trace elements, and suspended sediment. In addition, samples collected from two sites on lower Tenmile Creek during late-irrigation low flow in September were analyzed for chlorophenoxy herbicides.

Water in Tenmile Creek is a calcium bicarbonate type with relatively low concentrations of major ions and nutrients. Suspended-sediment concentrations were low, resulting in relatively clear water at most sites during the flow conditions sampled. For each sampling period, constituent concentrations generally increased in a downstream direction. Concentrations of most major ions, nutrients, and suspended sediment were lower in Tenmile Creek than in Sevenmile Creek throughout the range of flows sampled. With the exception of phosphorus at several sites, concentrations of major ions and nutrients were higher during low-flow (August and October) than during high-flow (June) conditions. Chlorophenoxy herbicides were not detected in any sample.

Measured concentrations of arsenic occasionally exceeded the State of Montana human-health standard for drinking water. The State of Montana aquatic-life standards for chronic toxicity for cadmium, copper, lead, and zinc were exceeded in several samples from Tenmile and Sevenmile Creeks. In addition, the acute toxicity standard for copper was exceeded in at least one sample from every site on Tenmile Creek. A similar pattern may have occurred for zinc, but this possibility cannot be determined conclusively due to zinc contamination that affected some samples.

An analysis of instantaneous loads indicates that most of the trace-element transport occurred during high-flow conditions (June). Although Sevenmile Creek contributed some trace-element load, most of the load transported to lower Tenmile Creek, especially during high flow, originated in the upper Tenmile Creek basin.

\section{REFERENCES CITED}

Briar, D.W., and Madison, J.P., 1992, Hydrogeology of the Helena valley-fill aquifer system, west-central Montana: U.S. Geological Survey WaterResources Investigations Report 92-4023, 92 p.

Edwards, T.K., and Glysson, G.D., 1988, Field methods for measurement of fluvial sediment: U.S.
Geological Survey Techniques of Water-

Resources Investigations, book 3, chap. C2, 80 p.

Hettinger, P.S., 1996, Integrating social assessment and biophysical characterization for watershed protection of upper Tenmile Creek near Helena, Montana: Missoula, University of Montana, M.S. thesis, $170 \mathrm{p}$.

Horowitz, A.J., Demas, C.R., Fitzgerald, K.K., Miller, T.L., and Rickert, D.A., 1994, U.S. Geological Survey protocol for the collection and processing of surface-water samples for the subsequent determination of inorganic constituents in filtered water: U.S. Geological Survey Open-File Report 94-539, $57 \mathrm{p}$.

Kendy, Eloise, Olsen, Bill, and Malloy, J.C., 1998, Field screening of water quality, bottom sediment, and biota associated with irrigation drainage in the Helena Valley, west-central Montana, 1995: U.S. Geological Survey Water-Resources Investigations Report 97-4214, $62 \mathrm{p}$.

Knapton, J.R., 1985, Field guidelines for collection, treatment, and analysis of water samples, Montana District: U.S. Geological Survey Open-File Report 85-409, 86 p.

Knapton, J.R., and Nimick, D.A., 1991, Quality assurance for water-quality activities of the U.S. Geological Survey in Montana: U.S. Geological Survey Open-File Report 91-216, 41 p.

Lambing, J.H., and Dodge, K.A., 1993, Quality assurance for laboratory analysis of suspendedsediment samples by the U.S. Geological Survey in Montana: U.S. Geological Survey Open-File Report 93-131, 34 p.

Montana Department of Environmental Quality, 1995, Montana numeric water quality standards: Helena, Mont., Water Quality Division Circular WQB 7, 39 p.

Montana Tunnels Mining, Inc., 1997, Quality assurance manual: Jefferson City, Mont., Water Quality Laboratory, revised May 10, 1997, variously paged.

National Oceanic and Atmospheric Administration, 1992, Monthly normals of temperature, precipitation, and heating and cooling degree days, 196190, Montana: Asheville, N.C., Climatography of the United States no. 81, unpaged.

Parrett, Charles, and Hettinger, P.S., 2000, Streamflow and water-quality characteristics in the upper Tenmile Creek watershed, Lewis and Clark County, west-central Montana: U.S. Geological Survey Water-Resources Investigations Report 00-4129, $71 \mathrm{p}$. 
Rantz, S.E., and others, 1982, Measurement and computation of streamflow: U.S. Geological Survey Water-Supply Paper 2175, 2 v., 631 p.

U.S. Environmental Protection Agency, 1983, Methods for chemical analysis of water and wastes: Cincinnati, Ohio, EPA Environmental Monitoring and Support Laboratory, EPA-600/4-79-020, variously paged.

U.S. Environmental Protection Agency, 1986, Quality criteria for water 1986: Washington, D.C., Office of Water Regulations and Standards, EPA 440/5-86-001, unpaged.

U.S. Environmental Protection Agency, 1991, Methods for the determination of organic compounds in drinking water: Washington, D.C., EPA Office of Research and Development, EPA/600/4-88/-39, method 515.1, p. 222 (July 1991 revision of Dec. 1988 report).

U.S. Environmental Protection Agency, 1996, Drinking water regulations and health advisories:
Washington, D.C., Office of Water, EPA 822-R-96-001, $11 \mathrm{p}$.

U.S. Geological Survey, 1977, National handbook of recommended methods for water-data acquisition--Chapter 5, Chemical and physical quality of water and sediment: U.S. Geological Survey Office of Water Data Coordination (International Hydrological Program), 193 p.

U.S. Salinity Laboratory Staff, 1954, Diagnosis and improvement of saline and alkali soils: U. S. Department of Agriculture Handbook 60, 160 p.

Ward, J.R., and Harr, C.A., eds., 1990, Methods for collection and processing of surface-water and bed-material samples for physical and chemical analyses: U.S. Geological Survey Open-File Report 90-140, $71 \mathrm{p}$.

White, M.K., Shields, R.R., and Dodge, K.A., 1998, Surface-water quality-assurance plan for the Montana District of the U.S. Geological Survey: U.S. Geological Survey Open-File Report 98-173, $54 \mathrm{p}$. 


\section{DATA}


Table 4. Analytical methods, minimum reporting levels, and water-quality standards for constituents analyzed in water samples from the lower Tenmile Creek watershed, Montana

[Abbreviations: $\mu \mathrm{g} / \mathrm{L}$, micrograms per liter; $\mathrm{mg} / \mathrm{L}$, milligrams per liter. Symbol: --, no standard established]

\begin{tabular}{|c|c|c|c|c|c|}
\hline \multirow{3}{*}{ Constituent } & \multirow{3}{*}{$\begin{array}{l}\text { Analytical } \\
\text { method }^{1}\end{array}$} & \multirow{3}{*}{$\begin{array}{c}\text { Minimum } \\
\text { reporting level }^{2}\end{array}$} & \multicolumn{3}{|c|}{ State of Montana water-quality standard ${ }^{3}$} \\
\hline & & & \multirow{2}{*}{ Human health } & \multicolumn{2}{|c|}{ Aquatic life } \\
\hline & & & & Acute & Chronic \\
\hline \multicolumn{6}{|c|}{ MAJOR IONS (dissolved, $\mathrm{mg} / \mathrm{L}$ ) } \\
\hline Calcium & 215.1 & 1 & - & -- & -. \\
\hline Magnesium & 242.1 & .1 & .- & -- & .. \\
\hline Sodium & 273.1 & .1 & -- & -- & -- \\
\hline Potassium & 258.1 & .1 & -- & .- & -. \\
\hline Sulfate & 300.0 & 1 & -. & -- & .. \\
\hline Chloride & 300.0 & 1 & -- & 860 & 230 \\
\hline Fluoride & 300.0 & .1 & 4 & -- & -- \\
\hline \multicolumn{6}{|c|}{ NUTRIENTS (dissolved, $\mathrm{mg} / \mathrm{L}$ ) } \\
\hline Nitrite $^{4}$ & 300.0 & .01 & 1 & _- & .- \\
\hline Nitrate $^{4}$ & 300.0 & .01 & 10 & -- & .- \\
\hline Ammonia ${ }^{4}$ & 350.3 & .05 & -- & 59.5 & ${ }^{5} 1.9$ \\
\hline Phosphorus ${ }^{4}$ & 365.3 & .01 & .- & -- & -. \\
\hline Orthophosphate $^{4}$ & 365.3 & .01 & -- & -- & - \\
\hline \multicolumn{6}{|c|}{ TRACE ELEMENTS $(\mu \mathrm{g} / \mathrm{L})^{6}$} \\
\hline Aluminum ${ }^{7}$ & 200.7 & 100 & - & 750 & 87 \\
\hline Arsenic & 206.2 & 3 & 18 & 360 & 190 \\
\hline Cadmium $^{8}$ & 213.2 & .1 & 5 & 3.9 & 1.1 \\
\hline Chromium $\mathrm{III}^{8}$ & 200.7 & 1 & 100 & 1,700 & 210 \\
\hline Copper $^{8}$ & 200.7 & 1 & 1,000 & 18 & 12 \\
\hline Iron 5 & 200.7 & 10 & 300 & -- & 1,000 \\
\hline Lead $^{8}$ & 239.2 & 3 & 15 & 82 & 3.2 \\
\hline Manganese $^{9}$ & 200.7 & 5 & 50 & - & $\ldots$ \\
\hline Mercury & 245.2 & 6 & .14 & 2.4 & .012 \\
\hline Nickel $^{8}$ & 200.7 & 20 & 100 & 1,400 & 160 \\
\hline Selenium & 270.2 & 1 & 50 & 20 & 5 \\
\hline Silver $^{8}$ & 200.7 & 3 & -. & 4.1 & .. \\
\hline Zinc $^{8}$ & 200.7 & ${ }^{10} 10$ & 5,000 & 120 & 110 \\
\hline \multicolumn{6}{|c|}{ HERBICIDES $(\mathrm{Mg} / \mathrm{L})$} \\
\hline Dalapon & 515.1 & 1.0 & 200 & -- & -- \\
\hline Dicamba (Banvel) & 515.1 & 1.0 & 11210 & .- & .- \\
\hline Dichloroprop & 515.1 & 1.0 & -- & -- & -. \\
\hline Dinoseb & 515.1 & .2 & 7 & -- & _. \\
\hline MCPA & 515.1 & $110^{.2}$ & ${ }^{11} 10.5$ & -- & -. \\
\hline MCPP & 515.1 & 110 & 7 & -. & $\ldots$ \\
\hline Pentachlorophenol & 515.1 & .04 & 1 & ${ }^{5} 5.3$ & $5_{4.0}$ \\
\hline Picloram (Tordon) & 515.1 & .1 & 500 & -- & .- \\
\hline 2,4-D & 515.1 & .1 & 70 & -- & -. \\
\hline $2,4-\mathrm{DB}$ & 515.1 & 1.0 & -- & _- & .. \\
\hline $2,4,5-\mathrm{T}$ & 515.1 & .1 & ${ }^{11} 70$ & .. & $\ldots$ \\
\hline 2,4,5-TP (Silvex) & 515.1 & .2 & 50 & .- & .. \\
\hline
\end{tabular}

${ }^{1}$ U.S. Environmental Protection Agency (1983, 1991); Montana Tunnels Mining, Inc. (1997).

${ }^{2}$ Minimum reporting level for major ion, nutrient, and trace element analyses by Montana Tunnels Water Quality Laboratory. Minimum reporting levels for replicate analyses by U.S. Geological Survey (for quality control) may differ. Minimum reporting level for herbicide analysis by Montana Department of Public Health and Human Services Chemistry Laboratory.

${ }^{3}$ Montana Department of Environmental Quality (1995).

${ }^{4} \mathrm{~A}$ plant nutrient, excessive amounts of which may cause violations of Administrative Rules of Montana (ARM) 16.20.633.(1)(e).

${ }^{5}$ Toxicity standards for ammonia are based on a pH of 7.7 and a temperature of 11.5 degrees Celsius. Toxicity standards for pentachlorophenol are based on a $\mathrm{pH}$ of 6.5 .

${ }^{6}$ Aquatic-life standards refer to total-recoverable concentrations, except for the standard for aluminum, which refers to the dissolved concentration.

${ }^{7}$ State of Montana aquatic-life standard for dissolved aluminum concentrations applicable only for pH between 6.5 and 9.0 .

${ }^{8}$ State of Montana aquatic-life standards are hardness dependent. Standards listed are based on total hardness of $100 \mathrm{mg} / \mathrm{L}$ as $\mathrm{CaCO}_{3}$. Equations for hardness-dependent criteria are presented in table 7.

${ }^{9}$ Human-health standard is for aesthetic purposes only.

${ }^{10}$ Minimum reporting level revised upward to $100 \mu \mathrm{g} / \mathrm{L}$ as a result of zinc contamination of sample preservative.

${ }^{11}$ Health advisory; not an enforceable standard. 
Table 5. Field-measured parameters and concentrations of major ions and nutrients in the lower Tenmile Creek watershed, Montana, 1997

[Samples analyzed by Montana Tunnels Laboratory unless otherwise indicated. Major ions and nutrients are reported as dissolved except for phosphorus. Identical sample dates for the same site indicate replicate samples analyzed to evaluate reproducibility of results. Abbreviations: ${ }^{\circ} \mathrm{C}$, degrees Celsius; inst., instantaneous; $\mu \mathrm{S} / \mathrm{cm}$, microsiemens per centimeter at $25^{\circ} \mathrm{C} ; \mathrm{mg} / \mathrm{L}$, milligrams per liter. Symbols: <, less than; --, no data]

\begin{tabular}{|c|c|c|c|c|c|c|c|c|c|c|}
\hline \multirow[b]{2}{*}{$\begin{array}{l}\text { Site number } \\
\text { (fig. 2) }\end{array}$} & \multirow[b]{2}{*}{ Date } & \multirow[b]{2}{*}{$\begin{array}{c}\text { Discharge, } \\
\text { inst. } \\
\text { (cubic feet } \\
\text { per second) }\end{array}$} & \multirow[b]{2}{*}{$\begin{array}{c}\text { Specific } \\
\text { conduct- } \\
\text { ance, } \\
\text { field } \\
(\mu \mathrm{S} / \mathrm{cm})\end{array}$} & \multirow[b]{2}{*}{$\begin{array}{c}\text { pH, } \\
\text { field } \\
\text { (standard } \\
\text { units) }\end{array}$} & \multirow[b]{2}{*}{$\begin{array}{c}\text { Tempera- } \\
\text { ture, } \\
\text { water } \\
\left({ }^{\circ} \mathrm{C}\right)\end{array}$} & \multicolumn{5}{|c|}{ Major ions } \\
\hline & & & & & & $\begin{array}{c}\text { Hardness } \\
\text { (mg/L as } \\
\left.\mathrm{CaCO}_{3}\right)\end{array}$ & $\begin{array}{c}\text { Calcium } \\
\text { (mg/L as } \\
\text { Ca) }\end{array}$ & $\begin{array}{c}\text { Magnesium } \\
\text { (mg/L as } \\
\mathrm{Mg})\end{array}$ & $\begin{array}{c}\text { Sodium } \\
\text { (mg/L as } \\
\mathrm{Na})\end{array}$ & $\begin{array}{l}\text { Sodium } \\
\text { adsorption } \\
\text { ratio }\end{array}$ \\
\hline \multirow[t]{6}{*}{34} & $06-05-97$ & 108 & 52.5 & 7.6 & 14.0 & 18 & 5.1 & 1.2 & 2.1 & 0.2 \\
\hline & $06-05-97^{1}$ & 108 & 52.5 & 7.6 & 14.0 & 18 & 5.4 & 1.2 & 2.2 & .2 \\
\hline & $08-27-97$ & 5.2 & 158 & 7.9 & 17.5 & 65 & 20 & 3.9 & 5.4 & .3 \\
\hline & $08-27-97^{1}$ & 5.2 & 158 & 7.9 & 17.5 & 68 & 20 & 4.6 & 5.4 & .3 \\
\hline & $10-08-97$ & 9.1 & 130 & 7.3 & 5.5 & 47 & 14 & 3.2 & 4.9 & .3 \\
\hline & $10-08-97^{1}$ & 9.1 & 130 & 7.3 & 5.5 & 47 & 13 & 3.3 & 4.9 & .3 \\
\hline \multirow[t]{3}{*}{40} & $06-04-97$ & 112 & 65.4 & 7.5 & 14.0 & 23 & 6.4 & 1.6 & 2.7 & .2 \\
\hline & $08-28-97$ & 8.1 & 219 & 8.0 & 12.0 & 93 & 28 & 5.9 & 8.9 & .4 \\
\hline & $10-09-97$ & 11 & 183 & 7.5 & 4.5 & 74 & 21 & 5.3 & 8.3 & .4 \\
\hline \multirow[t]{3}{*}{44} & $06-05-97$ & 101 & 87.0 & 7.7 & 10.5 & 31 & 8.7 & 2.2 & 3.8 & .3 \\
\hline & $08-28-97$ & 8.8 & 277 & 8.1 & 13.0 & 69 & 20 & 4.5 & 15 & .8 \\
\hline & $10-09-97$ & 18 & 240 & 7.7 & 4.0 & 90 & 25 & 6.6 & 13 & .6 \\
\hline \multirow[t]{3}{*}{$48^{2}$} & $06-05-97$ & 14 & 491 & 8.2 & 14.5 & 210 & 54 & 19 & 18 & .5 \\
\hline & $08-28-97$ & 4.1 & 604 & 8.0 & 11.5 & 280 & 71 & 25 & 25 & .7 \\
\hline & $10-09-97$ & 4.7 & 610 & 7.7 & 5.5 & 270 & 67 & 26 & 27 & .7 \\
\hline \multirow[t]{3}{*}{49} & $06-05-97$ & 119 & 144 & 8.1 & 13.5 & 53 & 14 & 4.3 & 5.7 & .3 \\
\hline & $08-28-97$ & 8.4 & 394 & 8.6 & 15.0 & 170 & 48 & 14 & 19 & .6 \\
\hline & $10-09-97$ & 14 & 351 & 7.9 & 5.5 & 150 & 38 & 12 & 17 & .6 \\
\hline \multirow[t]{4}{*}{54} & $06-05-97$ & 96 & 152 & 8.0 & 15.0 & 56 & 15 & 4.5 & 6.0 & .3 \\
\hline & $06-05-97^{1}$ & - & -- & - & - & 56 & 15 & 4.5 & 5.9 & .3 \\
\hline & $08-28-97$ & 3.0 & 381 & 8.1 & 17.5 & 170 & 47 & 12 & 16 & .5 \\
\hline & $10-09-97$ & 4.8 & 366 & 7.9 & 8.5 & 150 & 39 & 13 & 18 & .6 \\
\hline \multicolumn{11}{|c|}{ ELELD BLANKS } \\
\hline \multirow[t]{7}{*}{--} & $06-05-97$ & -- & 3.0 & 5.7 & -- & - & $<1.0$ & $<.1$ & $<.1$ & -- \\
\hline & $08-27-97$ & -- & 2.0 & 6.0 & 20 & $<10$ & $<1.0$ & $<.1$ & .4 & -- \\
\hline & $10-09-97$ & -- & -- & -- & -- & $<10$ & $<1.0$ & .2 & -- & -- \\
\hline & $10-09-97$ & -. & -. & -- & -- & $<10$ & $<1.0$ & .2 &.- & -- \\
\hline & $10-09-97$ & -- & -- & -- & -- & $<10$ & $<1.0$ & .1 & -- & -- \\
\hline & $10-09-97$ & -- & -- & -- & -- & $<10$ & $<1.0$ & .2 & -- & -- \\
\hline & $10-09-97$ & -- & -- & -- & -- & $<10$ & $<1.0$ & .3 & $<.1$ & -- \\
\hline
\end{tabular}

${ }^{1}$ Replicate sample analyzed by U.S. Geological Survey.

${ }^{2}$ Site 48 is on Sevenmile Creek. Other sites listed are on Tenmile Creek. 
Table 5. Field-measured parameters and concentrations of major ions and nutrients in the lower Tenmile Creek watershed, Montana, 1997 (Continued)

\begin{tabular}{|c|c|c|c|c|c|c|c|c|c|c|}
\hline \multicolumn{5}{|c|}{ Major ions } & \multicolumn{5}{|c|}{ Nutrients } & \multirow[b]{2}{*}{$\begin{array}{l}\text { Site number } \\
\quad \text { (fig. 2) }\end{array}$} \\
\hline $\begin{array}{c}\text { Potassium } \\
\text { (mg/L as } K)\end{array}$ & $\begin{array}{c}\text { Alka- } \\
\text { linity } \\
\text { (mg/L as } \\
\mathrm{CaCO}_{3}\end{array}$ & $\begin{array}{c}\text { Sulfate } \\
(\mathrm{mg} / \mathrm{L} \text { as } \\
\left.\mathrm{SO}_{4}\right)\end{array}$ & $\begin{array}{c}\text { Chloride } \\
\text { (mg/L as } \\
\text { Cl) }\end{array}$ & $\begin{array}{c}\text { Fluoride } \\
\text { (mg/L as F) }\end{array}$ & $\begin{array}{c}\text { Nitrite } \\
\text { (mg/L as } \\
\mathrm{N})\end{array}$ & $\begin{array}{l}\text { Nitrate } \\
(\mathrm{mg} / \mathrm{L} \text { as } \\
\mathrm{N})\end{array}$ & $\begin{array}{l}\text { Ammonia } \\
(\mathrm{mg} / \mathrm{L} \text { as } \mathrm{N})\end{array}$ & $\begin{array}{c}\text { Phos- } \\
\text { phorus } \\
(\mathrm{mg} / \mathrm{L} \text { as } \mathrm{P})\end{array}$ & $\begin{array}{c}\text { Ortho- } \\
\text { phos- } \\
\text { phate } \\
\left(\mathrm{mg}^{\prime} \mathrm{L} \mathrm{as}\right. \\
\left.\mathrm{PO}_{4}\right)\end{array}$ & \\
\hline 1.0 & 14 & 8.7 & $<1.0$ & $<0.10$ & $<0.01$ & 0.01 & $<0.05$ & 0.02 & $<0.01$ & 34 \\
\hline .9 & 14 & 8.1 & .5 & $<.10$ & $<.01$ & -- & $<.01$ & .03 & -- & \\
\hline 1.6 & 44 & 26 & 2.1 & $<.10$ & $<.01$ & $<.01$ & $<.05$ & .03 & .01 & \\
\hline 1.6 & 44 & 27 & 2.0 & $<.10$ & $<.01$ & $<.01$ & $<.05$ & .03 & .02 & \\
\hline 1.6 & 34 & 23 & 2.1 & $<.10$ & $<.01$ & $<.01$ & $<.05$ & .03 & .01 & \\
\hline 1.6 & 33 & 23 & 2.1 & $<.10$ & $<.01$ & $<.01$ & $<.05$ & .03 & .01 & \\
\hline 1.1 & 19 & 9.6 & 1.1 & $<.10$ & $<.01$ & .01 & $<.05$ & .03 & .01 & 40 \\
\hline 2.1 & 80 & 21 & 5.0 & .55 & $<.01$ & .11 & $<.05$ & .03 & .02 & \\
\hline 2.6 & 59 & 23 & 4.0 & .16 & $<.01$ & .06 & $<.05$ & .03 & .02 & \\
\hline 1.3 & 28 & 12 & 1.4 & $<.10$ & $<.01$ & .04 & $<.05$ & .03 & .01 & 44 \\
\hline 2.4 & 99 & 29 & 6.5 & .52 & $<.01$ & .17 & $<.05$ & .02 & .02 & \\
\hline 2.4 & 79 & 29 & 5.5 & .40 & $<.01$ & .10 & $<.05$ & .02 & .02 & \\
\hline 4.1 & 200 & 55 & 8.0 & .44 & $<.01$ & .08 & $<.05$ & .15 & .11 & $48^{2}$ \\
\hline 4.1 & 248 & 66 & 13 & .68 & $<.01$ & .08 & $<.05$ & .08 & .07 & \\
\hline 5.2 & 237 & 73 & 13 & .60 & $<.01$ & .20 & $<.05$ & .07 & .04 & \\
\hline 1.7 & 50 & 17 & 2.4 & .14 & $<.01$ & .04 & $<.05$ & .05 & .02 & 49 \\
\hline 3.1 & 157 & 43 & 8.7 & .56 & $<.01$ & $<.01$ & $<.05$ & .03 & .03 & \\
\hline 3.2 & 124 & 41 & 7.9 & .49 & $<.01$ & .10 & $<.05$ & $<.01$ & .02 & \\
\hline 1.7 & 53 & 18 & 2.7 & .11 & $<.01$ & .05 & $<.05$ & .06 & .02 & 54 \\
\hline 1.7 & 53 & 18 & 2.7 & .14 & $<.01$ & .05 & $<.05$ & .06 & .02 & \\
\hline 2.9 & 147 & 38 & 9.3 & .52 & $<.01$ & .05 & $<.05$ & .04 & .03 & \\
\hline 3.5 & 127 & 44 & 9.2 & .45 & $<.01$ & .09 & $<.05$ & .03 & .03 & \\
\hline \multicolumn{11}{|c|}{ FIELD BLANKS } \\
\hline$<.1$ & $<5$ & $<1.0$ & $<1.0$ & $<.10$ & $<.01$ & $<.01$ & $<.05$ & $<.01$ & $<.01$ & -- \\
\hline .2 & $<5$ & $<1.0$ & $<1.0$ & $<.10$ & $<.01$ & $<.01$ & $<.05$ & $<.01$ & $<.01$ & \\
\hline-- & -- & -- & -- & -- & -- & - & -- & -- & -. & \\
\hline-- & -- & -- & -- & -- & -- & -- & -- & -- & -- & \\
\hline -- & -- & -- & -- & -- & -- & -- & -- & -- & -- & \\
\hline -- & -- & -- & -- & -- & -- & -- & -- & -- & -- & \\
\hline$<.1$ & $<5$ & $<1.0$ & $<1.0$ & $<.10$ & $<.01$ & $<.01$ & $<.05$ & $<.01$ & $<.01$ & \\
\hline
\end{tabular}


Table 6. Concentrations of trace elements and suspended sediment in streams in the lower Tenmile Creek watershed, Montana, 1997

[Samples analyzed by Montana Tunnels Laboratory unless otherwise indicated. Shaded values indicate State of Montana human-health standard was equalled or exceeded. Values that equal or exceed standards for chronic aquatic-life toxicity are in boldface. Values that also equal or exceed standards for acute aquatic-life toxicity (if applicable) are in bold italics. Standards are shown in table 4. Identical sample dates for the same site indicate replicate samples analyzed to evaluate reproducibility of results. Abbreviations: inst., instantaneous; $\mu \mathrm{g} / \mathrm{L}$, micrograms per liter; mm, millimeter; rec., recoverable. Symbols: $<$, less than minimum reporting level; --, no data]

\begin{tabular}{|c|c|c|c|c|c|c|c|c|c|c|}
\hline $\begin{array}{l}\text { te number } \\
\text { (fig. 2) }\end{array}$ & Date & $\begin{array}{c}\text { Discharge, } \\
\text { inst. } \\
\text { (cubic feet } \\
\text { per second) }\end{array}$ & $\begin{array}{c}\text { Aluminum, } \\
\text { total rec. } \\
(\mu \mathrm{g} / \mathrm{L} \text { as } \mathrm{Al})\end{array}$ & $\begin{array}{c}\text { Arsenic, } \\
\text { total rec. } \\
(\mu \mathrm{g} / \mathrm{L} \text { as } \\
\text { As) }\end{array}$ & $\begin{array}{c}\text { Cadmium, } \\
\text { total rec. } \\
(\mu \mathrm{g} / \mathrm{L} \text { as Cd })\end{array}$ & $\begin{array}{c}\text { Cadmium, } \\
\text { dissolved } \\
(\mu \mathrm{g} / \mathrm{L} \text { as } \\
\text { Cd })\end{array}$ & $\begin{array}{l}\text { Chromium, } \\
\text { total rec. } \\
(\mu \mathrm{g} / \mathrm{L} \text { as } \mathrm{Cr})\end{array}$ & $\begin{array}{c}\text { Copper, } \\
\text { total rec. } \\
(\mu \mathrm{g} / \mathrm{L} \text { as } \\
\mathrm{Cu})\end{array}$ & $\begin{array}{c}\text { Copper, } \\
\text { dissolved } \\
(\mu \mathrm{g} / \mathrm{L} \text { as } \\
\mathrm{Cu})\end{array}$ & $\begin{array}{c}\text { Iron, } \\
\text { total rec. } \\
(\mu \mathrm{g} / \mathrm{L} \text { as } \mathrm{Fe})\end{array}$ \\
\hline
\end{tabular}

\begin{tabular}{|c|c|c|c|c|c|c|c|c|c|c|}
\hline \multirow[t]{6}{*}{34} & $06-05-97$ & 108 & 480 & 10 & 1.0 & 0.7 & $<1$ & 12 & 9 & 330 \\
\hline & $06-05-97^{1}$ & 108 & 240 & -- & ${ }^{2}<1$ & ${ }^{2}<1$ & $<1$ & 8 & 7 & 260 \\
\hline & $08-27-97$ & 5.2 & $<100$ & n(t) & .9 & .7 & $<1$ & 10 & 2 & 260 \\
\hline & $08-27-97^{1}$ & 5.2 & $<100$ & is & .9 & .7 & $<1$ & 13 & $<1$ & 250 \\
\hline & $10-08-97$ & 8.1 & $<100$ & $\pi s$ & 1.3 & 1.1 & $<1$ & 46 & 14 & 430 \\
\hline & $10-08-97^{1}$ & 8.1 & $<100$ & 17 & 1.3 & 1.1 & $<1$ & 43 & 14 & 430 \\
\hline \multirow[t]{3}{*}{40} & 06-04-97 & 112 & 540 & 14 & .8 & .6 & $<1$ & 12 & 8 & 400 \\
\hline & $08-28-97$ & 8.1 & $<100$ & 16 & .4 & .3 & $<1$ & $<1$ & $<1$ & 110 \\
\hline & $10-09-97$ & 10.7 & $<100$ & 16 & .5 & .5 & $<1$ & 30 & 6 & 240 \\
\hline \multirow[t]{3}{*}{44} & $06-05-97$ & 101 & 450 & 12 & .8 & .5 & $<1$ & 12 & 8 & 420 \\
\hline & $08-28-97$ & 8.8 & $<100$ & 16 & .3 & .2 & $<1$ & $<1$ & $<1$ & 80 \\
\hline & $10-09-97$ & 17.8 & $<100$ & 16 & .3 & .2 & $<1$ & 6 & 4 & 150 \\
\hline \multirow[t]{3}{*}{$48^{5}$} & $06-05-97$ & 14 & 540 & $2 ?$ & $<.1$ & $<.1$ & $<1$ & 9 & 4 & 520 \\
\hline & $08-28-97$ & 4.1 & 190 & $\because \%$ & $<.1$ & $<.1$ & $<1$ & 8 & $<1$ & 210 \\
\hline & $10-09-97$ & 4.7 & 340 & 14 & $<.1$ & $<.1$ & $<1$ & 31 & 1 & 500 \\
\hline \multirow[t]{3}{*}{49} & $06-05-97$ & 119 & 650 & 15 & .8 & .4 & $<1$ & 12 & 7 & 570 \\
\hline & $08-28-97$ & 8.4 & $<100$ & r & .1 & $<.1$ & $<1$ & 15 & $<1$ & 110 \\
\hline & $10-09-97$ & 14 & $<100$ & 16 & .1 & $<.1$ & $<1$ & 22 & 2 & 170 \\
\hline \multirow[t]{4}{*}{54} & $06-05-97$ & 96.5 & 790 & 16 & .8 & .2 & $<1$ & 14 & 8 & 770 \\
\hline & $06-05-97^{1}$ & 96.5 & 750 & 16 & .7 & .2 & $<1$ & 13 & 7 & 750 \\
\hline & $08-28-97$ & 3.0 & $<100$ & 17 & .1 & $<.1$ & $<1$ & 9 & $<1$ & 140 \\
\hline & $10-09-97$ & 4.8 & -- & -- & -- & -- & -- & - & -- & -. \\
\hline \multicolumn{11}{|c|}{ FIELD BLANKS } \\
\hline \multirow[t]{7}{*}{-. } & $06-05-97$ & -- & $<100$ & $<3$ & $<.1$ & $<.1$ & $<1$ & 1 & 1 & $<10$ \\
\hline & $08-27-97$ & -- & $<100$ & $<3$ & $<.1$ & $<.1$ & $<1$ & $<1$ & $<1$ & $<10$ \\
\hline & $10-09-97$ & -- & $<100$ & $<3$ & $<.1$ & -- & $<1$ & $<1$ & -- & $<10$ \\
\hline & $10-09-97$ & -- & $<100$ & $<3$ & $<.1$ & - & $<1$ & $<1$ & -- & $<10$ \\
\hline & $10-09-97$ & -- & $<100$ & $<3$ & $<.1$ & -- & $<1$ & $<1$ & -- & $<10$ \\
\hline & $10-09-97$ & -- & $<100$ & $<3$ & $<.1$ & -- & $<1$ & $<1$ & -- & $<10$ \\
\hline & $10-09-97$ & -- & $<100$ & $<3$ & $<.1$ & $<.1$ & $<1$ & $<1$ & $<1$ & $<10$ \\
\hline
\end{tabular}

${ }^{1}$ Analyzed by U.S. Geological Survey.

${ }^{2}$ Minimum reporting level greater than State of Montana chronic aquatic-life standard (Montana Department of Environmental Quality, 1995); unable to determine if exceedances occurred.

${ }^{3}$ Minimum reporting level greater than State of Montana chronic aquatic-life standard and human-health standard (Montana Department of Environmental Quality, 1995).

${ }^{4}$ Minimum reporting level for environmental samples changed to $100 \mu \mathrm{g} / \mathrm{L}$ because of contamination found in field blanks.

${ }^{5}$ Site 48 is on Sevenmile Creek. Other sites listed are on Tenmile Creek. 
Table 6. Concentrations of trace elements and suspended sediment in streams in the lower Tenmile Creek watershed, Montana, 1997 (Continued)

\begin{tabular}{|c|c|c|c|c|c|c|c|c|c|c|c|}
\hline $\begin{array}{c}\text { Lead, } \\
\text { total rec. } \\
(\mu \mathrm{g} / \mathrm{L} \text { as } \\
\mathrm{Pb})\end{array}$ & $\begin{array}{c}\text { Lead }^{2} \text {, } \\
\text { dissolved } \\
(\mu \mathrm{g} / \mathrm{L} \text { as } \\
\text { Pb) }\end{array}$ & $\begin{array}{c}\text { Manga- } \\
\text { nese, } \\
\text { total } \\
\text { rec. } \\
(\mu \mathrm{g} / \mathrm{L} \text { as } \\
\mathrm{Mn})\end{array}$ & $\begin{array}{c}\text { Mercury }^{3} \text {, } \\
\text { total } \\
\text { rec. } \\
(\mu \mathrm{g} / \mathrm{L} \text { as } \\
\mathrm{Hg})\end{array}$ & $\begin{array}{c}\text { Nickel, } \\
\text { total } \\
\text { rec. } \\
(\mu \mathrm{g} / \mathrm{L} \text { as } \\
\mathrm{Ni})\end{array}$ & $\begin{array}{c}\text { Selenium, } \\
\text { total } \\
\text { rec. } \\
(\mu \mathrm{g} / \mathrm{L} \text { as } \\
\text { Se })\end{array}$ & $\begin{array}{c}\text { Silver, } \\
\text { total rec. } \\
(\mu \mathrm{g} / \mathrm{L} \text { as } \\
\mathrm{Ag})\end{array}$ & $\begin{array}{c}\text { Zinc }^{4}, \\
\text { total } \\
\text { rec. } \\
(\mu \mathrm{g} / \mathrm{L} \text { as } \\
\mathrm{Zn})\end{array}$ & $\begin{array}{c}\text { Zinc }^{4} \\
\text { dissolved } \\
(\mu \mathrm{g} / \mathrm{L} \text { as } \\
\mathrm{Zn})\end{array}$ & $\begin{array}{l}\text { Sediment, } \\
\text { suspended } \\
(\mu \mathrm{g} / \mathrm{L})\end{array}$ & $\begin{array}{c}\text { Sediment }{ }^{1} \text {, } \\
\text { sus- } \\
\text { pended, } \\
\text { sieve } \\
\text { diameter } \\
<0.062 \\
\text { mm } \\
\text { (percent) }\end{array}$ & $\begin{array}{l}\text { Site number } \\
\quad \text { (fig. 2) }\end{array}$ \\
\hline 10 & $<3$ & 32 & $<0.6$ & $<20$ & $<1$ & $<3$ & 140 & 130 & 6,000 & 83 & 34 \\
\hline$<3$ & $<1$ & 25 & $<.6$ & 1 & -- & $<1$ & 140 & 140 & 7,000 & 68 & \\
\hline${ }^{2}<3$ & $<3$ & 15 & $<.6$ & $<20$ & -- & $<3$ & 160 & 140 & 3,000 & 86 & \\
\hline${ }^{2}<3$ & $<3$ & 12 & $<.6$ & $<20$ & $\cdot \quad--$ & $<3$ & 160 & 160 & 4,000 & 81 & \\
\hline 3 & $<3$ & 33 & $<.6$ & $<20$ & $<1$ & $<3$ & 320 & 310 & 3,000 & 88 & \\
\hline 3 & $<3$ & 31 & $<.6$ & $<20$ & $<1$ & $<3$ & 310 & 290 & 3,000 & 69 & \\
\hline 3 & $<3$ & 41 & $<.6$ & $<20$ & $<1$ & $<3$ & 120 & 130 & 12,000 & 60 & 40 \\
\hline 4 & $<3$ & 16 & $<.6$ & $<20$ & -- & $<3$ & $<100$ & $<100$ & 2,000 & 63 & \\
\hline${ }^{2}<3$ & $<3$ & 15 & $<.6$ & $<20$ & 1 & $<3$ & 150 & 130 & 15,000 & 83 & \\
\hline 6 & $<3$ & 39 & $<.6$ & $<20$ & $<1$ & $<3$ & 140 & 140 & 19,000 & 51 & 44 \\
\hline${ }^{2}<3$ & $<3$ & 13 & $<.6$ & $<20$ & -- & $<3$ & $<100$ & $<100$ & 2,000 & 81 & \\
\hline${ }^{2}<3$ & $<3$ & 9 & $<.6$ & $<20$ & 1 & $<3$ & $<100$ & $<100$ & 3,000 & 77 & \\
\hline 4 & $<3$ & 53 & $<.6$ & $<20$ & $<1$ & $<3$ & $<100$ & $<100$ & 34,000 & 75 & $48^{5}$ \\
\hline$<3$ & $<3$ & 36 & $<.6$ & $<20$ & -- & $<3$ & $<100$ & $<100$ & 42,000 & 67 & \\
\hline 3 & $<3$ & 44 & $<.6$ & $<20$ & $<1$ & $<3$ & $<100$ & $<100$ & 21,000 & 83 & \\
\hline 10 & $<3$ & 48 & $<.6$ & $<20$ & $<1$ & $<3$ & 100 & $<100$ & 25,000 & 61 & 49 \\
\hline$<3$ & $<3$ & 42 & $<.6$ & $<20$ & -- & $<3$ & $<100$ & $<100$ & 4,000 & 92 & \\
\hline$<3$ & $<3$ & 29 & $<.6$ & $<20$ & $<1$ & $<3$ & $<100$ & $<100$ & 4,000 & 84 & \\
\hline 5 & $<3$ & 62 & $<.6$ & $<20$ & $<1$ & $<3$ & $<100$ & $<100$ & 30,000 & 80 & 54 \\
\hline 7 & $<3$ & 59 & $<.6$ & $<20$ & $<1$ & $<3$ & $<100$ & $<100$ & 30,000 & 79 & \\
\hline$<3$ & $<3$ & 79 & $<.6$ & $<20$ & -- & $<3$ & $<100$ & $<100$ & 4,000 & 90 & \\
\hline-- & -- & -- & -- & -- & -- & -- & -- & - & 5,000 & 90 & \\
\hline \multicolumn{12}{|c|}{ FIELD BLANKS } \\
\hline$<3$ & $<3$ & $<5$ & $<.6$ & $<20$ & $<1$ & $<3$ & $<10$ & 40 & -- & -- & -. \\
\hline$<3$ & $<3$ & $<5$ & $<.6$ & $<20$ & -- & $<3$ & 100 & 50 & -- & -- & \\
\hline$<3$ & -- & $<5$ & -- & $<20$ & $<1$ & $<3$ & $<70$ & -- & -- & -- & \\
\hline$<3$ & -- & $<5$ & - & $<20$ & $<1$ & $<3$ & $<10$ & -- & -- & -- & \\
\hline$<3$ & -- & $<5$ & -- & $<20$ & $<1$ & $<3$ & $<10$ & -- & -- & -- & \\
\hline$<3$ & -- & $<5$ & -- & $<20$ & $<1$ & $<3$ & $<10$ & -- & -- & -- & \\
\hline$<3$ & $<3$ & $<5$ & $<.6$ & $<20$ & $<1$ & $<3$ & $<10$ & $<10$ & -- & -- & \\
\hline
\end{tabular}


Table 7. Equations for calculation of State of Montana freshwater aquatic-life standards based on ambient hardness 1

[As used in these equations, hardness is reported in $\mathrm{mg} / \mathrm{L}$ of $\mathrm{CaCO}_{3}$. For hardness values less than $25 \mathrm{mg} / \mathrm{L}$, the aquatic-life standard is the same as that for a hardness value of $25 \mathrm{mg} / \mathrm{L}$. For hardness values greater than $400 \mathrm{mg} / \mathrm{L}$, the aquatic-life standard is the same as that for a hardness of $400 \mathrm{mg} / \mathrm{L}$. Abbreviations: $\mu \mathrm{g} / \mathrm{L}$, micrograms per liter; $\mathrm{mg} / \mathrm{L}$, milligrams per liter. Symbol: e, base of natural logarithms, equal to 2.718 ; --, no standard]

\begin{tabular}{lll}
\hline \multirow{2}{*}{ Trace element } & \multicolumn{1}{c}{ State of Montana freshwater aquatic-life standard, in $\mu \mathrm{g} / \mathrm{L}$} \\
\cline { 2 - 3 } Cadmium & \multicolumn{1}{c}{ Acute toxicity } & \multicolumn{1}{c}{ Chronic toxicity } \\
Chromium III & $\mathrm{e}^{(1.128[\ln (\text { hardness })]-3.828)}$ & $\mathrm{e}^{(0.7852[\ln (\text { hardness })]-3.490)}$ \\
Copper & $\mathrm{e}^{(0.8190[\ln (\text { hardness })]+3.688)}$ & $\mathrm{e}^{(0.8190[\ln (\text { hardness })]+1.561)}$ \\
Lead & $\mathrm{e}^{(0.9422[\ln (\text { hardness })]-1.464)}$ & $\mathrm{e}^{(0.8545[\ln (\text { hardness })]-1.465)}$ \\
Nickel & $\mathrm{e}^{(1.273[\ln (\text { hardness })]-1.460)}$ & $\mathrm{e}^{(1.273[\ln (\text { hardness })]-4.705)}$ \\
Silver & $\mathrm{e}^{(0.8460[\ln (\text { hardness })]+3.3612)}$ & $\mathrm{e}^{(0.8460[\ln (\text { hardness })]+1.1645)}$ \\
Zinc & $\mathrm{e}^{(1.72[\ln (\text { hardness })]-6.52)}$ & -- \\
\hline
\end{tabular}

${ }^{1}$ Montana Department of Environmental Quality (1995). 
Table 8. Instantaneous trace-element and suspended-sediment loads in the lower Tenmile Creek watershed, Montana, 1997

[Instantaneous trace-element and suspended-sediment loads expressed as daily transport rates were calculated from total-recoverable concentrations by multiplying concentration by flow by 0.0054 . For total-recoverable concentrations that were less than the reporting level, instantaneous loads were calculated from one-half the minimum reporting levels. For replicate samples, loads were calculated using the average concentration. Symbol: <, less than. --, no data]

\begin{tabular}{|c|c|c|c|c|c|c|c|c|c|}
\hline \multirow{2}{*}{$\begin{array}{c}\text { Site } \\
\text { num- } \\
\text { ber }\end{array}$} & \multirow[b]{2}{*}{ Date } & \multicolumn{7}{|c|}{ Instantaneous load, in pounds per day } & \multirow{2}{*}{$\begin{array}{c}\text { Sus- } \\
\text { pended } \\
\text { sediment }\end{array}$} \\
\hline & & $\begin{array}{c}\text { Alumi- } \\
\text { num }\end{array}$ & Arsenic & $\begin{array}{l}\text { Cad- } \\
\text { mium }\end{array}$ & Copper & Iron & Lead & $\begin{array}{l}\text { Man- } \\
\text { ganese }\end{array}$ & \\
\hline 34 & $\begin{array}{l}06 / 05 / 97 \\
08 / 27 / 97 \\
10 / 08 / 97\end{array}$ & $\begin{array}{l}210 \\
<1.4 \\
<2.2\end{array}$ & $\begin{array}{l}5.8 \\
.52 \\
.79\end{array}$ & $\begin{array}{r}0.44 \\
.03 \\
.06\end{array}$ & $\begin{array}{l}5.8 \\
.31 \\
2.0\end{array}$ & $\begin{array}{c}170 \\
7.1 \\
19\end{array}$ & $\begin{array}{l}3.4 \\
<.04 \\
.13\end{array}$ & $\begin{array}{l}17 \\
.38 \\
1.4\end{array}$ & $\begin{array}{r}3,800 \\
98 \\
130\end{array}$ \\
\hline 40 & $\begin{array}{l}06 / 04 / 97 \\
08 / 28 / 97 \\
10 / 09 / 97\end{array}$ & $\begin{array}{l}330 \\
<2.2 \\
<2.9\end{array}$ & $\begin{array}{l}8.5 \\
.7 \\
.92\end{array}$ & $\begin{array}{l}.48 \\
.02 \\
.03\end{array}$ & $\begin{array}{l}7.3 \\
<.02 \\
1.7\end{array}$ & $\begin{array}{c}240 \\
4.8 \\
14\end{array}$ & $\begin{array}{r}1.8 \\
.18 \\
<.09\end{array}$ & $\begin{array}{r}25 \\
.70 \\
.87\end{array}$ & $\begin{array}{r}7,300 \\
88 \\
870\end{array}$ \\
\hline 44 & $\begin{array}{l}06 / 05 / 97 \\
08 / 28 / 97 \\
10 / 09 / 97\end{array}$ & $\begin{array}{l}250 \\
<2.4 \\
<4.8\end{array}$ & $\begin{array}{l}6.5 \\
.76 \\
1.5\end{array}$ & $\begin{array}{l}.44 \\
.01 \\
.03\end{array}$ & $\begin{array}{l}6.5 \\
<.03 \\
.58\end{array}$ & $\begin{array}{c}230 \\
3.8 \\
14\end{array}$ & $\begin{array}{l}3.3 \\
<.07 \\
<.15\end{array}$ & $\begin{array}{l}21 \\
.62 \\
.87\end{array}$ & $\begin{array}{r}10,000 \\
95 \\
290\end{array}$ \\
\hline $48^{1}$ & $\begin{array}{l}06 / 05 / 97 \\
08 / 28 / 97 \\
10 / 09 / 97\end{array}$ & $\begin{array}{l}41 \\
4.2 \\
8.6\end{array}$ & $\begin{array}{l}1.6 \\
.42 \\
.36\end{array}$ & $\begin{array}{l}<.005 \\
<.005 \\
<.005\end{array}$ & $\begin{array}{l}.68 \\
.18 \\
.79\end{array}$ & $\begin{array}{c}39 \\
4.6 \\
13\end{array}$ & $\begin{array}{r}.30 \\
<.03 \\
.08\end{array}$ & $\begin{array}{c}4.0 \\
.80 \\
1.1\end{array}$ & $\begin{array}{r}2,600 \\
930 \\
530\end{array}$ \\
\hline 49 & $\begin{array}{l}06 / 05 / 97 \\
08 / 28 / 97 \\
10 / 09 / 97\end{array}$ & $\begin{array}{l}420 \\
<2.3 \\
<3.8\end{array}$ & $\begin{array}{c}9.6 \\
.82 \\
1.2\end{array}$ & $\begin{array}{c}.51 \\
<.005 \\
.01\end{array}$ & $\begin{array}{l}7.7 \\
.68 \\
1.7\end{array}$ & $\begin{array}{c}370 \\
5.0 \\
13\end{array}$ & $\begin{array}{l}6.4 \\
<.07 \\
<.12\end{array}$ & $\begin{array}{l}31 \\
1.9 \\
2.2\end{array}$ & $\begin{array}{r}16,000 \\
180 \\
300\end{array}$ \\
\hline 54 & $\begin{array}{l}06 / 05 / 97 \\
08 / 28 / 97 \\
10 / 09 / 97 \\
\end{array}$ & $\begin{array}{l}400 \\
<0.80 \\
- \\
\end{array}$ & $\begin{array}{l}8.3 \\
.28 \\
-- \\
\end{array}$ & $\begin{array}{r}.39 \\
<.005 \\
-- \\
\end{array}$ & $\begin{array}{l}7.0 \\
.15 \\
-. \\
\end{array}$ & $\begin{array}{c}400 \\
2.3 \\
-- \\
\end{array}$ & $\begin{array}{l}3.1 \\
<.02 \\
-- \\
\end{array}$ & $\begin{array}{c}32 \\
1.3 \\
-- \\
\end{array}$ & $\begin{array}{r}16,000 \\
65 \\
130 \\
\end{array}$ \\
\hline
\end{tabular}

${ }^{1}$ Site 48 is on Sevenmile Creek. Other sites listed are on Tenmile Creek. 
